\title{
A study on the Hydrogeology and Hydrogeochemistry of groundwater from different depths in a coastal aquifer - Annamalai Nagar, Tamilnadu, India
}

\author{
Chidambaram. S, Senthil Kumar. G*, Prasanna M.V., John Peter. A, Ramanthan AL* and \\ Srinivasamoorthy K \\ Department of Earth Sciences, Annamalai University, Annamalai Nagar. \\ *School of Environmental Sciences, JNU, New Delhi, 110057
}

\begin{abstract}
Chemical characterization of groundwater is essential to bring out its nature and utility. Samples from shallow and deep ground water of the same locations were collected and studied for their geochemical characteristics. Sediment samples from different depths were collected and analyzed minerals using Fourier transform infrared spectroscopy (FTIR) and scanning electron microscope (SEM) The resisitivity logging was carried out in the bore well to understand the variations in depth to fresh water potential. The shallow ground water is dominated by $\mathrm{Na}-\mathrm{Cl}-\mathrm{HCO}_{3}-\mathrm{SO}_{4}$ and deeper groundwater by $\mathrm{Na}-\mathrm{HCO}_{3}-$ $\mathrm{SO}_{4}-\mathrm{Cl}$ types. It is observed that there is a significant ionic variation with depth. The ionic strength of the deeper samples is lesser than shallower. Wide $\mathrm{pH}$ variations in the shallow water samples are due to ion exchange process. The thermodynamic stability plot was used to identify the state of stability. It is inferred that there is no major significant difference in the thermodynamic state of stability in the shallow and the deeper aquifers as the aquifer matrix for the shallow and deeper aquifers are almost similar. Saturation index of gibbsite, kaolinite, calcite, dolomite and anhydrite were studied for shallow and deep aquifers, to identify the difference in hydro chemical signatures. The $\mathrm{Si} / \mathrm{Al}$ ratios of shallow samples are less when compared to the deeper samples. Leaching of secondary salts was the chief mechanism controlling the ground water chemistry of the region.
\end{abstract}

\section{Key Words}

Groundwater, Resistivity log, Coastal aquifer hydrogeochemistry, Thermodynamic stability, Saturation Index. 


\section{Introduction}

Aquifers in the coast are generally fragile and in most of the regions the shallow aquifers are easily depleted due to over exploitation of groundwater. The deeper aquifers are comparatively of lesser contamination. In the areas of extensive extraction, characterization of shallow and deeper aquifers are essential to elucidate their geochemical nature and its relation to aquifer matrix. Annamalai University belongs to Annamalai Nagar Township, which lies in eastern side of Chidambaram, the taluk headquarters of Cuddalore district, Tamilnadu. The campus area is about 1000 acres, north of the river Coleroon, which join to the Bay of Bengal. Chidambaram is located $250 \mathrm{Km} \mathrm{SW}$ of Chennai. The area is located between the geographical coordinates, latitudes of $11^{\circ} 20^{\prime}-11^{\circ} 25^{\prime}$ and between longitudes of $79^{\circ} 42^{\prime}-79^{\circ} 45^{\prime}$. The region falls in the topo sheet of $58 \mathrm{M} / 11$ covering an area of about 1000 acres (Fig.1). Annamalai Nagar is linked to Chidambaram town by metal road for $2 \mathrm{~km}$. Chidambaram is linked to the main cities by roadways. The area suffers tropical climate with maximum temperature observed during May and the minimum in December. There is good amount of rainfall during the NE monsoon (October - December) and scanty in the SW monsoon (June September). There is an average rainfall of 1500mm/yr (Senthil Kumar,2006).

In Annamalai Nagar in the past two decades local village people are using shallow aquifers for the agricultural and domestics purposes. The deep bore wells are mainly used for the university utility purposes, and now few rich farmers and housing societies are going for the deep ground water exploration. Shallow groundwaters were observed to be contaminated by agricultural activities (present and abandoned, Senthil Kumar,2006) . Full fledged concrete structures and buildings have reduced the recharge of the shallow groundwaters (Senthil Kumar, 2006). Annamalai university campus composed of more than 15000 people at present using deeper wells for the university hostel and staff quarters consumption , since deep groundwater were less contaminated and are potential. In this scenario, this study is undertaken to address the availability and chemical characterization of the water it also focuses on aquifer lithology in the shallow and deep groundwaters of the region. 
The various aspects attempted for first time in this paper on they are; 1 . To understand the geological and hydro geological aspects of shallow and deeper groundwater 2. To delineate exactly the ground water potential zone, thickness of the zone, using subsurface geophysical methods 3. To understand the complexity of hydrogeochemical process operating in these aquifers.

\section{Geology}

The Geology of the area plays a significant role in the determination of the groundwater potential of the region. The area is represented by sedimentary formation composed of clays and sand of quaternary age. The area shows low undulating topography with the elevation of 5.75 meters from the MSL. There is a gradual slope towards the coastal region. The area contains mainly of aquifer and aquicludes. The first sub artesian aquifer found at a depth of 200 meters. This aquifer has some microfossil of textulaira and globigerina (Lakshmanan,1982). Species present in the aquifer indicates Miocene age. The lower aquifer is cretaceous, according to unpublished reports of Public Works Department. Geological succession of the near by area is given below the Table 1 .

\section{Drainage}

The Khan Saheb canal, which originates from the lower anicut, runs in the northern side of the university campus. The Uspur channel runs south of the campus. The entire region is of gentle slope towards Southeast. There are three main reservoir tanks present in this region (Fig. 1). Rettaikulam the north and south of the university road, Vellakulam reservoir near the Engineering Block and Tiruvetkulam temple tank the are storage structures of the region.

\section{Aquifer Parameters:}

The pump test data of the shallow wells reveals that transmissivity ranges from $800 \mathrm{gpd} /$ feet to $850 \mathrm{gpd} /$ feet. Deep bore well (400 meters) at the University pavilion has 45300 gpd/feet (635mз / day /m) (Lakshmanan, 1982 and Arul 1990). Hence it is believed that the deep bore wells in the campus have high transmissivity. The " $K$ " values in the shallow well also reflect the lesser hydraulic conductivity than the deep wells. The K 
values of the shallow wells ranges from $29.74 \mathrm{gpd} / \mathrm{ft}^{2}$ to $77.86 \mathrm{gpd} / \mathrm{ft}^{2}$ and the deep university pavilion well has 394.5 gpd / $\mathrm{ft}^{2}$, which is invariably having larger aquifer thickness. Hence, the transmissivity and hydraulic conductivity of the deeper wells are greater. By applying the relationship, the thickness of the aquifer yielding to the pavilion well is approximately $35.27 \mathrm{~m}$ and similarly for the shallow wells range from $8.07 \mathrm{~m}$ to $3.298 \mathrm{~m}$.

\section{Water table:}

The water table helps us to determine the direction of movement of water and approximately the location of the catchment area. The water level studies by earlier authors (Lakshmanan, 1982, Arul 1990 and Senthilkumar 2006) reveals that the ground water flows from the SE to the NW in the eastern side of the campus. The earlier studies also point out that the movement of water was based on the Coleroon River and the Khan Saheb canal. During 1980 the depth of the water table in the open wells were observed to range from $1.88 \mathrm{~m}$ to $2.87 \mathrm{~m}$. The recent water level detail indicates that the table ranges from 7 to 10 meters and the deepest water level present at NE side of the study area., and the movement is generally form the south west to north east due to large scale extraction in this region.

\section{Subsurface investigations}

The resistivity log of four different locations along AA'(Fig.1) in the study area is shown in Figure.3. From the NW end, the following well logs are displayed, DDE, new engineering block, ladies hostel and agricultural college. The investigations reveals that the DDE well has two aquifers one is shallow (70-80 meters) and other deeper aquifer (>150 meters). In the new engineering block borehole again two categories of aquifers shallow (85 -110 meters) and deep (>160 meters) are noted. The depth of logging for the ladies hostel was up to 250 meters, the log indicates the existence of a small aquifer at $60-80 \mathrm{~m}$ and another at $105-130 \mathrm{~m}$. Agricultural college bore well indicates that good potential aquifer exist only below 200 meters (figure 2). This clearly points out the absence of shallow aquifer in the region. All the shallow aquifers are extensively used of for agricultural and domestic purposes. 
The Resistivity log shows the variation between shallow and deep aquifers, the shallow aquifer starts at $30 \mathrm{mbgl}$ in the west and reached $60 \mathrm{~m}$ in the south east. The figure 3 show the inclination of the aquifer towards southeast. Similarly the potential deep aquifer, which starts at $140 \mathrm{mbgl}$ at DDE, is observed at $210 \mathrm{mbgl}$ at agricultural college. The self potential log of the bore well near the hospital site and western hostel were observed and compared with the resistivity log of the study area. The western hostel bore well shows that the shallow aquifer occurs at a depth of $45-66 \mathrm{~m}$ and the second potential aquifer at $100 \mathrm{~m}$. The third potential aquifer was found at a depth $205 \mathrm{~m}$ depth in the same borehole. The borehole near hospital site depicts shallow aquifer at 32m and intermediate at $104 \mathrm{~m}$ and deep at 224m . The shallow, intermediate and deep potential aquifers are all dipping towards the south east of the study area. The study of these subsurface geophysical records reveals the presence of stacked bars and channels in this region. The presence of these features also gives an idea of the coastal instability during the geological past.

The three dimensional picture (Figure 3) depicting the spatial distribution of the subsurface resistivity in four different boreholes clearly shows different zones of resistivity. There are three prominent zones with high resistivity in the Ladies hostel bore well. These may be the regions with relatively fresh water. It is also evident that the extent of this shallow fresh water is restricted a small patch is visible in the Engineering college bore well. The extent of fresh water in deep bore well is more. It also possible to witness the variation lithology with respect to the resistivity values, the upper layer in the DDE bore and in the agriculture college is clayey. The resistivity log indicate the inter fingering of the clay lenses with the sandy layer or silty sand and is visible to certain extent (Fig.3 ).However, SP log has also to be compared to get a complete idea about the lithology.

\section{Mineralogy}

Fourier transform infrared spectroscopy ( JEOL-JSM- 5610 LV ) were measured for the samples. The freeze dried clay and sediment samples, 7-10 mg, was added to $300 \mathrm{mg}$ spectrograde $\mathrm{KBr}$, and mixed thoroughly in a Wig-L-Bug for five minutes under dry $\mathrm{N}_{2}$ 
in a glove box. A portion of the mixed sample, $150 \mathrm{mg}$, was weighed, degassed, and pelletized also under dry $\mathrm{N}_{2}$. The transmission spectrum of the resulting pellet was obtained from 256 scans with a nominal resolution

of $8 \mathrm{~cm}$-t in the $4000-600 \mathrm{~cm} \sim$ region. A reference spectrum of $\mathrm{KBr}$ was subtracted to yield the final clay spectrum. The system software was capable of baseline correction, subtraction, and peak deconvolution of the spectra measured.

Sediment samples were collected from the bore well in site A at 10 ' intervals upto a depth of about 680', FTIR (Fourier transform infrared spectroscopy) analysis was carried out for the sediment samples collected. The samples representing specific depth the first aquifer, second aquifer and the deeper aquifer were analysed (figures 4,5 and 6). The clay layers separating these aquifers were also analyzed (Table 2). The FTIR analysis shows the presence of Quartz, kaolinite and montmorllionite at shallow aquifer and Quartz and kaolinite in the deeper aquifer. Certain other minor peaks were also noticed but have not been identified in detail. The relationship between the mineralogy and water chemistry of these aquifers help us to get an insight into the residence time and the water rock interaction process (Krishna et al 1992). Characterization of clay minerals in the Brahmaputra river sediments, Assam (Kotoky et al 2007), has highlighted the use of Fourier transform infrared spectra and has revealed the association of dominant kaolinite with subordinate amount of Illite and chlorite. Similar studies highlighting the importance of FTIR in mineral identifications were also carried out by Georges-Ivo (2005), Worden et al (2006) and Ojima (2003)

In general all the aquifers are chiefly composed of Quartz which is the more resistant mineral towards weathering. The feldspars and other mafic minerals have under gone chemical alteration to form clay minerals. The clays formed may be due to insitu weathering, this insitu weathering is a result of interaction of the water in the aquifer with feldspars. Feldspars are converted to clay minerals as kaolinite, Smectite, Illite, Montmorllionite, etc., the samples from the depth 27-30 m in Figure 7 and of 197 - $200 \mathrm{~m}$ in Figure 8 were subjected to SEM analysis to find out the micro morphology of the clay minerals and their relationship to non clay minerals. 
The SEM photograph of the grain size from the shallow depth of $27 \mathrm{~m}$ in figure 7 indicates a definite structure and the Electron diffraction spectra (EDS) chiefly of Si, $\mathrm{Al}$, Sr and K. So probably the mineral grain under focus is orthoclase with distinct two sets of cleavage. The layering or stratification was noticed in the mineral from SEM photograph. EDS shows the dominant elements are oxides of Si, Fe, Al and Ca. Minor percentage of $\mathrm{Na}, \mathrm{Mg}$ and $\mathrm{Sr}$ were also noted, the clay mineral at this stage of development may be montmorllionite. These cations occur as the common exchangeable ions, the inter layer cations of this smectite group of clay may be already in the specimen or formed as a result of subsequent exchange, since some cations are more readily substituted than others (Deer, et al 1963). Analysis of clay sample of the deeper depth of $197 \mathrm{~m}$, indicate that the minerals were made up of kaolinite and chlorite. The scanning electron microscope shows a picture in the form of books (Figure 8). The composition of the mineral is chiefly composed of greater percentage of $\mathrm{Al}$ and $\mathrm{Si}$ as oxides and very minor percentage of Sr. The composition is similar to kaolinite, it occurs in compact massive blocks or granular aggregates or as piles of platelets. A layer of composition ( $\left.\mathrm{Si}_{4} \mathrm{O}_{10}\right)_{-4}$ is formed with the linkage of $\mathrm{SiO}_{4}$ tetrahedra in a hexagonal array and the base of the tetrahedra being approximately coplanar and their vertices all-pointing in one direction. The removal of silica from the lattice planes and enrichment of cations by ion exchange in the $\mathrm{Al}$ dominant clays are noted for the chemical composition obtained from EDS. The silica removed from the matrix is introduced into the water medium, thereby enriching the silica concentration in ground waters. The structures which appear linear are similar to chlorite. The composition from EDS also shows that they are made up of $\mathrm{Al}$ and Mg.

\section{Results and Discussion}

The chemical constituents of shallow and deep aquifers indicate that $\mathrm{Na}$ behaves as the dominant ion (Table 3).

\section{Water type}

The dominant cations and anions present in water are generally reflected in the water type (Piper,1944). The prominent chemical facies of the shallow groundwater ( Figure 9) is 
$\mathrm{Na}-\mathrm{Cl}-\mathrm{HCO}_{3}-\mathrm{SO}_{4}$ and that of deeper groundwater is and $\mathrm{Na}-\mathrm{HCO}_{3}-\mathrm{SO}_{4}-\mathrm{Cl}$ ( Figure 10). High sodium waters can be explained by the combination of dilution factors, ion exchange and Sulphate reduction (Krothe 1982). The increased hydrogen ion concentration in water also reduces the $\mathrm{pH}$ of ground waters at certain locations. Increased chloride concentration (conservative ion) in shallow groundwater may be due to the process of removal of other anions from the system either by adsorption to clays or through other hydrochemical processes In shallow groundwater lesser amount of $\mathrm{Ca}, \mathrm{Mg}$ and $\mathrm{HCO}_{3}$ may be due to the precipitation and removal of ions as calcite, dolomite, or Aragonite leaving the $\mathrm{Na}-\mathrm{Cl}$ dominated groundwaters.

In deeper aquifer $\mathrm{Na}-\mathrm{HCO}_{3}$ type water is dominant. This may be due to the consumption of $\mathrm{H}^{+}$ions during the chemical weathering alteration of Feldspar to clay. $\mathrm{H}^{+}$ions are introduced in depth by sulphate reduction and methanoorganism in the near surface environment by oxidation of organic matter and pyrite. There is also a probability of loss of $\mathrm{Ca}$ and $\mathrm{Mg}$ and gain of $\mathrm{Na}+$ by cation exchange with $\mathrm{Na}$ rich Smectite clays(R) (Wallick 1981).

$\mathrm{RNa}+\mathrm{Ca}_{2}+$ or $\mathrm{Mg}_{2+}=\mathrm{RCa} / \mathrm{Mg}+2 \mathrm{Na}$

\section{EC Vs IS}

Ionic strength of a sample is directly related to the molality and charge of ions (Garrels and Christ 1965). The ionic strength of the deeper groundwaters samples range from 0.01 to 0.03 and that of shallow ground water range from 0.015 to 0.05 (Figure 11). The low ionic strength of the samples from the deeper aquifers indicates the depletion of dissolved ions due to the removal of ions by precipitation of minerals or by dilution or due to lesser extent of weathering/contamination. Hence, in deeper aquifer the dissolved ions are lesser compared to the shallow aquifers. The conductivity is a measure of TDS in water. The EC of deeper groundwater samples ranges from 500 to $2000 \mu \mathrm{s} / \mathrm{cm}$, but in shallow aquifer it ranges from 100 to $4500 \mu \mathrm{s} / \mathrm{cm}$. The clustering of samples were noted in the lower EC and IS in deeper aquifers. Marked steep linearity of EC and IS in the shallow ground waters than that of deeper ground water samples, shows that, the ions dissolved in the deeper water samples are less than shallow samples 


\section{Thermodynamic stability}

The stages of structural breakdown of minerals can be established by the stability filed of the silicate minerals. Hence standard stability diagrams were evolved for the thermodynamic studies (Garrels and Christ 1965 and Stumm and Morgan 1996). In spite of some limitations, a major application of these diagrams is that one can plot the appropriate ion activities for a given sample of water to evaluate the water composition status in terms of mineral-water equilibrium. Similar studies were adopted for well waters in the black soil zone over weathered Deccan basalt of Malwa Plateau, Madhya Pradesh (Lunkad and Raymahashay, 1978). The thermodynamic stability studies were also applied to, groundwater in lateritic soil profiles of Kerala and its composition is found to be in consistent with occurrence of Gibbsite, kaolinite and halloysite (Raymahashay, et al,1987).

\section{Na system}

All samples fall in kaolinite to montmorllionite field. The samples of deeper aquifer are grouped near the boundary of stability zone between kaolinite and Na-montmorllionite. Most of samples of shallow groundwater fall in the kaolinite field (Figure 12). There is a wide of variation of $\mathrm{Na}$ or $\mathrm{pH}$ in shallow ground water than in deeper ground waters. The chemical composition of this water is in equilibrium with the kaolinite and montmorllionite. Diagenesis affects the relative mass of the secondary minerals as a function of reaction progress (controlled by Temp, Depth , Pressure) (Helgesson 1969). Paragenesis and relative mass of authigenic minerals produced may be due to hydrolysis of existing K-Feldspar and Albite. It's assumed that sediments and water are in a closed system and no intermediate reaction products are removed from the system physically. The position of the samples in the stability plot shows that they are in equilibrium with kaolinite initially and later due to the availability of cations and silica the equilibrium is shifted to montmorllionite (Krauskopf,1979):

$1.17 \mathrm{Al}_{2} \mathrm{Si}_{2} \mathrm{O}_{5}(\mathrm{OH})_{4}+0.16 \mathrm{Na}_{2}++1.33 \mathrm{H}_{4} \mathrm{SiO}_{4}=\mathrm{Na} 0.167 \mathrm{Al}_{2.33} \mathrm{Si} 3.67 \mathrm{O}_{10}(\mathrm{OH})_{2}+0.33 \mathrm{H}$ $+3.83 \mathrm{H}_{2} \mathrm{O}$ 
It is evident form the figure that the shallow groundwaters are represented with low and high $\mathrm{Na}$ due to availability of $\mathrm{Na}$ or due to the variation of $\mathrm{pH}$. The higher $\mathrm{pH}$ may also be due to the absorption of $\mathrm{H}+$ into the clay lattice resulting in the exchange of cations at the exchange sites.

$\mathrm{R}+$-clay $+2 \mathrm{H}+\mathrm{OH}$ - = H- clay $+\mathrm{R}++\mathrm{H}_{2} \mathrm{O}$

Na- Montmorllionite is more stable with this composition than Ca- Montmorllionite, this may be due to the removal of $\mathrm{Ca} / \mathrm{Mg}$ from the system by precipitation or due to the lesser mobility.

\section{K System}

In K system the samples fall in three different fields kaolinite, Muscovite and KFeldspar. Most of the shallow water samples fall in the kaolinite stability field, few in muscovite and K-Feldspar (Figure 13).Similar to Na system here again shallow water samples fall in two groups with low and high $\mathrm{K} / \mathrm{H}$ values. Samples with high $\mathrm{K} / \mathrm{H}$ values show higher $\mathrm{pH}$ ( equation 2). The Possibility of the state of stability at the muscovite and feldspar field may be explained by the following reactions (Drever,1988):

1. Mica to kaolinite

$$
2 \mathrm{KAl}_{3} \mathrm{Si}_{3} \mathrm{O}_{10}(\mathrm{OH})_{2}+2 \mathrm{H}^{+}+\mathrm{H}_{2} \mathrm{O}=3 \mathrm{Al}_{2} \mathrm{Si}_{2} \mathrm{O}_{5}(\mathrm{OH})_{4}+2 \mathrm{~K}^{+}
$$

2. Dissolution of K-Feldspar to K-Mica

$$
3 \mathrm{KAlSi}_{3} \mathrm{O}_{8}+2 \mathrm{H}^{+}+2 \mathrm{H}_{2} \mathrm{O}=\mathrm{KAl}_{3} \mathrm{Si}_{3} \mathrm{O}_{10}(\mathrm{OH})_{2}+6 \mathrm{H}_{4} \mathrm{SiO}_{4}+2 \mathrm{~K}^{+}
$$

3. Weathering of K-Feldspar to kaolinite

$$
\mathrm{KAlSi}_{3} \mathrm{O}_{8}+4 \mathrm{Al}(\mathrm{OH})_{3}+\mathrm{H}_{2} \mathrm{O}=3 \mathrm{Al}_{2} \mathrm{Si}_{2} \mathrm{O}_{5}(\mathrm{OH})_{4}+2 \mathrm{~K}^{+}+2(\mathrm{OH})^{-}
$$

The Probability of the reaction 1 is lesser as it involves the decrease of $\mathrm{H}+$ ions, this release will gradually decrease the $\mathrm{pH}$ of the system, on contradictory high $\mathrm{pH}$ values are noted in this waters. It is also possible to favor the reverse of this reaction, which 
consume $\mathrm{H}$ and increase the $\mathrm{pH}$ of the system. Hence the reverse of reaction 1 is possible for the shallow ground water which falls in the muscovite field and reaction 3 for samples clustered in the kaolinite field or due to ion exchange thereby bringing down the $\mathrm{pH}$. Reaction 2 might be dominant one in the deeper waters. It is also possible that the deeper samples are stable with $\mathrm{K}$ feldspar or along the ' $\mathrm{Y}$ ' boundary between kaolinite, muscovite and $\mathrm{K}$ feldspar. It indicates certain samples are approaching ' $\mathrm{K}$ ' feldspar stability either by addition of $\mathrm{K}$ and $\mathrm{H}_{4} \mathrm{SiO}_{4}$ to kaolinite

\section{Mg system}

The samples fall in kaolinite and chlorite stability fields. Here again similar to $\mathrm{Na}$ and $\mathrm{K}$ system two groups with lesser and higher $\mathrm{Mg} / \mathrm{H}$ in shallow ground waters. The deeper groundwater samples fall between them along the boundary of kaolinite and Chlorite Figure 14. There is a possibility of continuous spectrum existing between Illite breakdown in weathering and illite formation during diagenesis. In more active regions with good regional flow, Illite would tend to weather to kaolinite, while in the stagnant regions Illite is formed in the aquitard regions. There are two reaction mechanisms are postulated (Wallick 1981) for solubility of Mg in waters

(i) First by formation of Illite by reaction of biotite, K-Feldspar and montmorllonite during diagenesis. The molal ratio $\mathrm{K} / \mathrm{Mg}$ is these waters where transition take place is 0.51

(ii) The second reaction is weathering of Illite to kaolinite, which has a molal ratio around 2.4 .

From the figure 15 it is clear that both mechanism are prominent in the study area, the first seems to be more predominant in the shallow aquifers. In the deeper aquifers both of are dominant. There are dissimilarities in ratio of certain ions in few locations it may be due to stability of these samples with different stages of clay mineral transition, which is beyond the purview of this study.

\section{Statistical analysis}




\section{Correlation}

The correlation analysis (significant at the level of 0.05) of shallow groundwaters shows that, good correlation exist between $\mathrm{HCO}_{3}, \mathrm{~K}, \mathrm{Na}, \mathrm{Cl} ; \mathrm{K}, \mathrm{Cl}$ and $\mathrm{HCO}_{3}$. Negative correlation exists between $\mathrm{pH}, \mathrm{Ca}, \mathrm{Mg}, \mathrm{K}$; $\mathrm{Ca}, \mathrm{Mg}, \mathrm{Na}, \mathrm{K}, \mathrm{SO} 4$, and $\mathrm{Na}$. A schematic correlation diagram is represented as follows,

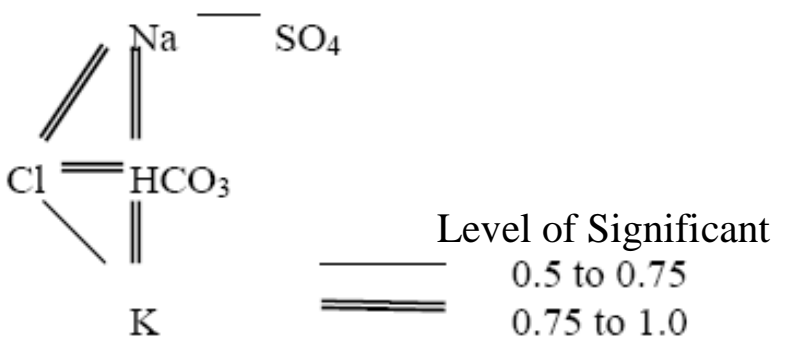

In deeper groundwater good correlation exists between $\mathrm{Cl}, \mathrm{HCO}_{3}$; $\mathrm{Na}, \mathrm{Cl}, \mathrm{HCO}_{3}$; and $\mathrm{pH}$, $\mathrm{SO}_{4}$ and $\mathrm{Na}$, no strong negative correlations were established, but other ions shows poor positive to poor negative correlation. A schematic representation for deeper aquifer is given below,

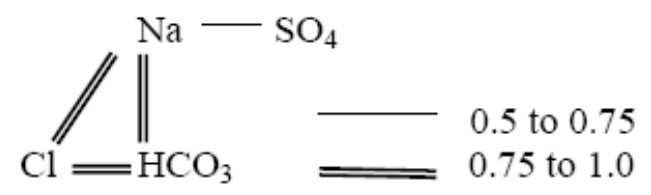

The basic correlation exists between $\mathrm{Na}, \mathrm{Cl}, \mathrm{HCO}_{3}$ and $\mathrm{SO}_{4}$, which form the Spinal species i.e. chief component ions (Srinivasamoorthy et al, 2005) in both the depths. The water chemistry shows that $\mathrm{K}$ is well correlated with $\mathrm{Cl}$ and $\mathrm{HCO}_{3}$ at shallow depths, but it lacks good correlation with other ions in deeper aquifer (Table 4).

\section{Factor analysis}

The factor analyses were carried out for the groundwater samples collected in the study area. Three factors were extracted for shallow groundwater samples representing $78 \%$ of the hydrogeochemical process (Table 5). The extraction of three factors from the available data set reveals that it's a complex hydrogeochemical system. The first and 
second factors are dominant among the three processes extracted. $\mathrm{Cl}, \mathrm{HCO}_{3}, \mathrm{Ca}$ and $\mathrm{Na}$ represent the first factor indicating the leaching and dissolution of secondary salts precipitated in the pore spaces. Neagtive $\mathrm{K}$ and $\mathrm{Ca}$ with positive $\mathrm{pH}$ represent the second factor. The $\mathrm{pH}$ representation in this factor indicates the enhanced $\mathrm{pH}$ values or the removal of $\mathrm{H}_{+}$in the system along with $\mathrm{K}$. This may be due to the normal mica weathering process release these ions and $\mathrm{H}+$ into the system or by ion exchange. The third factor is represented by $\mathrm{K}$ and $\mathrm{H}_{4} \mathrm{SiO}_{4}$, this may be due to the enrichment of silica by silicate weathering.

In the deeper groundwater four factors were extracted representing $83 \%$ of the total data variability. The first factor is more dominant in the hydrogeochemical system. $\mathrm{Cl}, \mathrm{Na}$ and $\mathrm{HCO}_{3}$, indicating the leaching and dissolution of secondary salts in the pore spaces representing first factor and $\mathrm{K}, \mathrm{Mg}$ and $\mathrm{H} 4 \mathrm{Sio} 4$ represents the second factor indicating silicate weathering. Third factor is represented by $\mathrm{pH}$ and $\mathrm{SO}_{4}$ where hydrogen is removed from the system and $\mathrm{SO}_{4}$ were added to the system due to reverse reaction.

$\mathrm{CH}_{2}+1 / 2 \mathrm{SO}_{4}{ }^{2}=1 / 2 \mathrm{HS}+\mathrm{HCO}_{3}+1 / 2 \mathrm{H}$

The forward reaction involves the release of $\mathrm{H}+$ ions introduced at depth by sulphate reduction and methanogenesis by oxidation of organic matter (Wallick 1981). The reverse of this reaction consumes $\mathrm{H}$ thereby increasing $\mathrm{pH}$ and release $\mathrm{SO}_{4}$ into the system. Fourth factor is represented by HCO3 only due the dissolution of secondary carbonaceous leacheates. Thus the statistical analysis reveals that dissolution and leaching of secondary salts along with ion exchange process plays a dominant role in hydrogeochemistry of the region.

\section{Saturation index}

\section{Silicate minerals}

The structural breakdown of aluminium silicates is accompanied by a release of cations usually with silicic acid. As a result of such reactions alkalinity is impaired to the dissolved phase from the bases of the minerals. In most silicate phases $\mathrm{Al}$ is conserved 
during the reaction, the solid residue being higher in $\mathrm{Al}$ than the original silicate, the alkalinity of the solution increases during the weathering process, the solid residue has higher acidity than the original aluminium silicate (Stumm and Morgan 1996). Hence the ratio of $\mathrm{Si} / \mathrm{Al}$ determines the state of thermodynamic equilibrium of water. The saturation index of secondary minerals (kaolinite and Gibbsite) is plotted against the mole ratio of Si and Al. The (SI: Saturation Index) SIgibbsiteis $<2.5$ and SIkaolinite is $>2.5$ ( Figure 16). There is a clear demarcation between SIgibbsiteand SIkaolinite. It also shows that SIkaolinite > SIgibbsitein samples of both the depths. Si/Al ratio reveals that in most of the samples ,there is a clear grouping, most of the shallow ground water samples have ratio less in $\mathrm{Si} / \mathrm{Al}$ values $(<2.5 \mathrm{ppm})$. There are few shallow groundwater samples showing higher value, this may be due to the increased dissolution of $\mathrm{H}_{4} \mathrm{SiO}_{4}$ in the system or enrichment of $\mathrm{Al}$ in the solid phase induces the formation of secondary minerals promoting higher saturation index for these secondary minerals and higher alkalinity to the system (Stumm and Morgan,1996).

\section{Carbonate minerals}

The figure 17 shows that the Saturation Index of calcite and aragonite are plotted against $\mathrm{PCO}_{2}$, it varies from under saturation to saturation, where SIcalcite $>$ SIaragonite. The figure also reveals that, $\mathrm{PCO}_{2}$ decreases when saturation index increases. This process of decrease in $\mathrm{PCO}_{2}$ will aid in the precipitation and removal of $\mathrm{CaCO} 3$ form the system (Chidambaram et al, 2007). Similar conditions are also noted in SI dolomite and SI magnesite against $\mathrm{PCO}_{2}$.

But the magnesite shows near saturation to equilibrium condition with increase of $\mathrm{PCO}_{2}$. The changing state of equilibrium from saturation to under saturation of $\mathrm{CO}_{3}$ minerals in these waters are expected to be around $-2.25 \mathrm{ppm} \log \mathrm{PCO}_{2}$. There is no clear demarcation between shallow and deep ground waters with respect to saturation index of carbonates minerals. 


\section{Conclusion}

The shallow water type is dominated by Na-Cl-HCO $3-\mathrm{SO}_{4}$ and deeper groundwater by $\mathrm{Na}-\mathrm{HCO}_{3}-\mathrm{SO}_{4}-\mathrm{Cl}$. In shallow groundwaters lesser amount of $\mathrm{Ca}, \mathrm{Mg}$ and $\mathrm{HCO}_{3}$ occur, may be due to the precipitation and removal of ions as calcite, dolomite, or aragonite. Na and $\mathrm{Cl}$ are the dominant ions in shallow ground waters. The lower ionic strength is noted in the samples of deeper aquifers due to less dissolved ions, or removal of ions by precipitation. The thermodynamic stability reveals that shallow water is in equilibrium with kaolinite and montmorllionite. The shallow groundwater has lower and higher $\mathrm{pH}$ ( 2 groups) which is due to the process of ion exchange. This process is felicitated by the occurrence of intervening clay layers in the shallow aquifers. The deeper water samples are grouped into specific region in the stability plots with not much variation in their respective fields. The correlation exists between $\mathrm{Na}, \mathrm{Cl}, \mathrm{HCO}_{3}$ and $\mathrm{SO}_{4}$, shows the possible formation of spinal species at both depths. The factor analysis reveal that leaching of secondary salts remains the chief mechanism controlling water chemistry in both the depths, but ion exchange and weathering are dominant in the shallow depth. The deeper aquifer shows signatures of methanogenesis. SIkaolinite $>$ SIgibbsitein samples of both the depths. Si/Al ratio reveals a clear grouping, most of the shallow groundwater samples have low $\mathrm{Si} / \mathrm{Al}$ ratio. There is a decrease of $\mathrm{PCO}_{2}$ values with increase of saturation index of carbonate minerals, which helps in their precipitation and removal from the liquid phase. There is no clear demarcation of shallow and deep ground waters with respect to Saturation Index of carbonates, as higher and low SI of carbonate minerals are observed in both the depths.

\section{Reference:}

1. APHA (1998) Standard methods for the examination of water and wastewater, $19^{\text {th }}$ edition. APHA, Washington DC, USASS

2. Arul P (1990) Geophysical and hydrological studies of A.U. Campus, Annamalai Nagar, Tamil Nadu, 98p. 
3. Chidambaram S, Vijayakumar V, Srinivasamoorthy K, Anandhan P, Prasanna MV, and Vasudevan S (2007). A study on variation in ionic composition of aqueous system in different lithological units around Cuddalore regions Tamil nadu India. Journal of Geological Society of India

4. Deer,WA, Howie,RA and Zussman,J (1963) Rock-Forming Minerals. Volume 4, Framework Silicates. Longmans, 435pp

5. Drever,JI, (1988), Geochemistry of natural waters, $2^{\text {nd }}$ edition, Eagle wood cliffs NJ(Eds) Prentice Hall 388p

6. Garrels, R. M., and J. C.Christ. (1965). Solutions, minerals, and equilibria. San Francisco: Freeman, Cooper, JAIC 1992, Volume 31, Number 3, Article 7, pp. 355 to 366.

7. Georges-ivo E. Ekosse (2005) Fourier Transform Infrared Spectrophotometry and X-ray powder Diffractometry as Complementary Techniques in characterizing Clay size fraction of Kaolin J. Appl. Sci. Environ. Mgt Vol. 9 (2) 43 - 48

8. Helgessan H. C. (1969) - Thermodynamics of hydrothermal systems at elevated temperatures and pressures. American. Jour. Science, Vol. 267; pp 729-804

9. Jay Bassin N. (1975) Suspended marine clay mineral identification by scanning electron microscopy and energy-dispersive X-ray analysis, American Society of Limnology and Oceanography Vol. 20, Issue 1, Pg 136

10. Kotoky P., P. Bezbaruah P Baruah J,. Borah G. C and J. N. Sarma (2006). Characterization of clay minerals in the Brahmaputra river sediments, Assam, India. Current science, vol. 91, no. 9, 1247-1250pp 
11. Krauskopf (1979) Introduction to Geochemistry $2^{\text {nd }}$ Edition, Mc Graw hill international Services, Singapore. 617p

12. Krishna Bukka,. Miller J. D and Joseph Shabtai (1992) FTIR study of deuterated Montmorillonites: structural Features relevant to pillared clay stability, Clays and Clay Minerals, Vol. 40, No. 1, 92-102,

13. Krothe, N.C., and Oliver, J.W., (1982), Sulfur isotopic composition and water chemistry from the High Plains aquifer, Oklahoma panhandle and southwestern Kansas:U.S. Geological Survey Water Resources Investigations 82-12, 28 p.

14. Lakshmanan AR, Krishna Rao T, Viswanathan S (1982) Nitrate and fluoride level in drinking waters of Hyderabad. India, Journal of Environmental Health 28 - 1: pp39- 47

15. Lakshmanan S (1982) Hydrogeological studies of Annamalai University Campus, pp. 92.

16. Lunkad S. K. and B. C. Raymahashay (1978), Ground water quality in weathered Deccan Basalt of Malwa Plateau, India, Quarterly Journal of Engineering Geology and Hydrogeology , volume 11: 273-277

17. Ojima J. (2003) determining of crystalline silica in respirable dust samples by infrared spectrophotometry in the presence of interferences. Journal of Occupational Health 45, 94-103

18. Piper A.M (1944), A graphic procedure in geochemical interpretation of water analysis. Trans Geophysics union 25:914-923 
19. Raymahashay B. C., K. S. Rao, V. K. Mehta and P. R. Bhavana (1987), Mineralogy and geochemistry of lateritic soil profiles in Kerala, India, Chemical Geology, Volume 60, Issues 1-4, 10 March 1987, pp 327-330

20. Richard H. Worden, Sarah J. Needham and Javier Cuadros (2006). “The worm gut; a natural clay mineral factory and a possible cause of diagenetic grain coats in sandstones” Journal of Geochemical Exploration, Volume 89, Issues 1-3, April-June, 428-431 pp

21. Russ, J. C. (1971). Energy dispersion X-ray analysis on the scanning electron microscope In Energy dispersion X-ray analysis and electron probe analysis. Am. Sot. Testing Mater. Spec. Pub. 485. p.154-179

22. Senthilkumar G, (2006). Hydrogeochemical studies in and around Annamalai Nagar Region Tamilnadu, India. M.Sc dissertation, Dept. of Earth sciences, Annamalai University, Tamilnadu, India. 120p.

23. Srinivasamoorthy K, Chidambaram S and Anandan P,(2005) Equilibrium and thermodynamic approach of groundwater chemistry from a hard rock terrain, Mettur, A case Salem district, Tamilnadu. Indian Journal of Geochemistry, Vol. 20,181-190pp.

24. Stumm, W. and Morgan, J. J. (1996), Aquatic Chemistry, Wiley Interscience, New York, U.S.A.,. Pp. 349-424

25. Wallick E. I. (1981) Chemical evolution of groundwater in a drainage basin of Holocene age, east-central Alberta, Canada, Journal of Hydrology, Volume 54, Issues 1- 3, December 1981, pp 245-283 


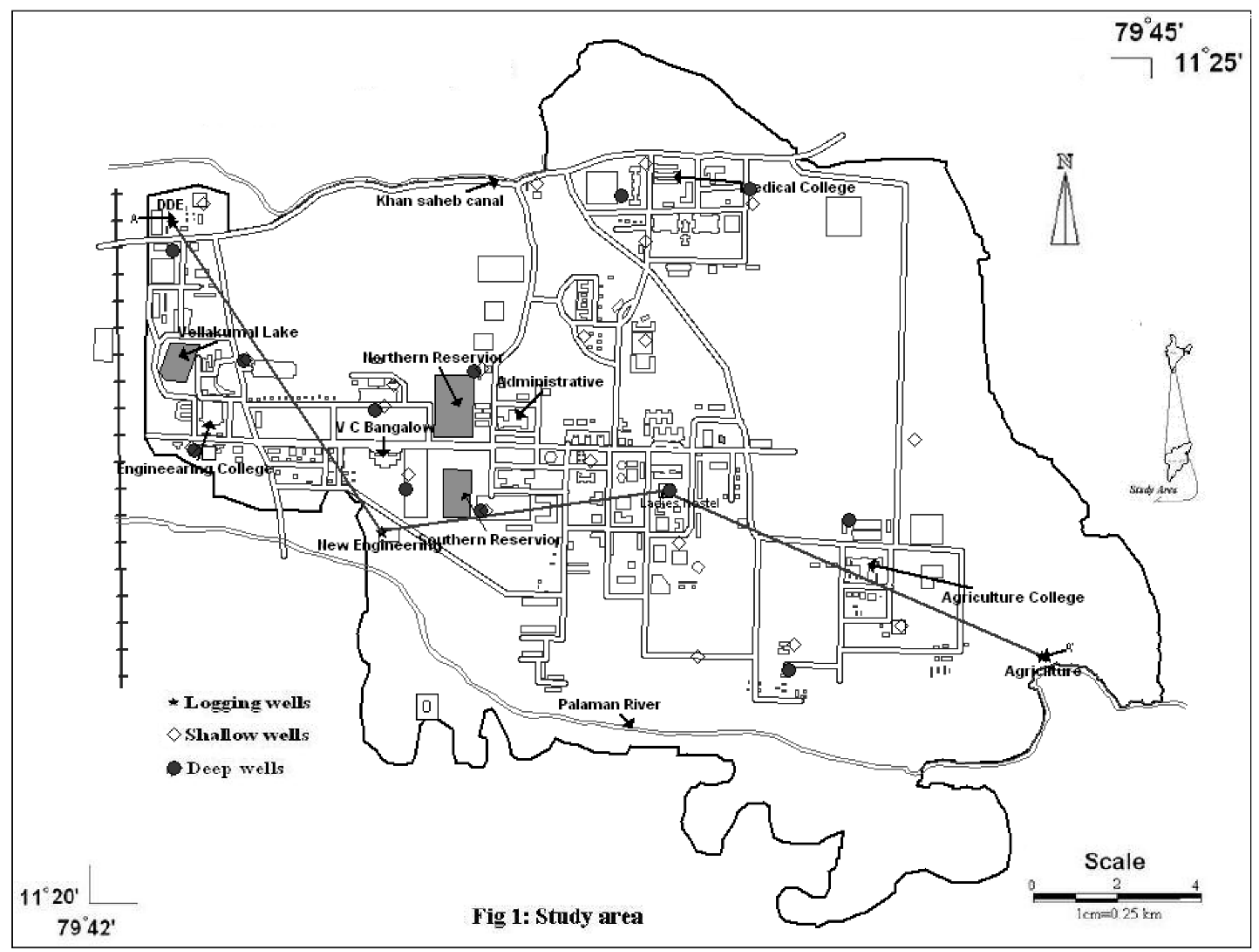




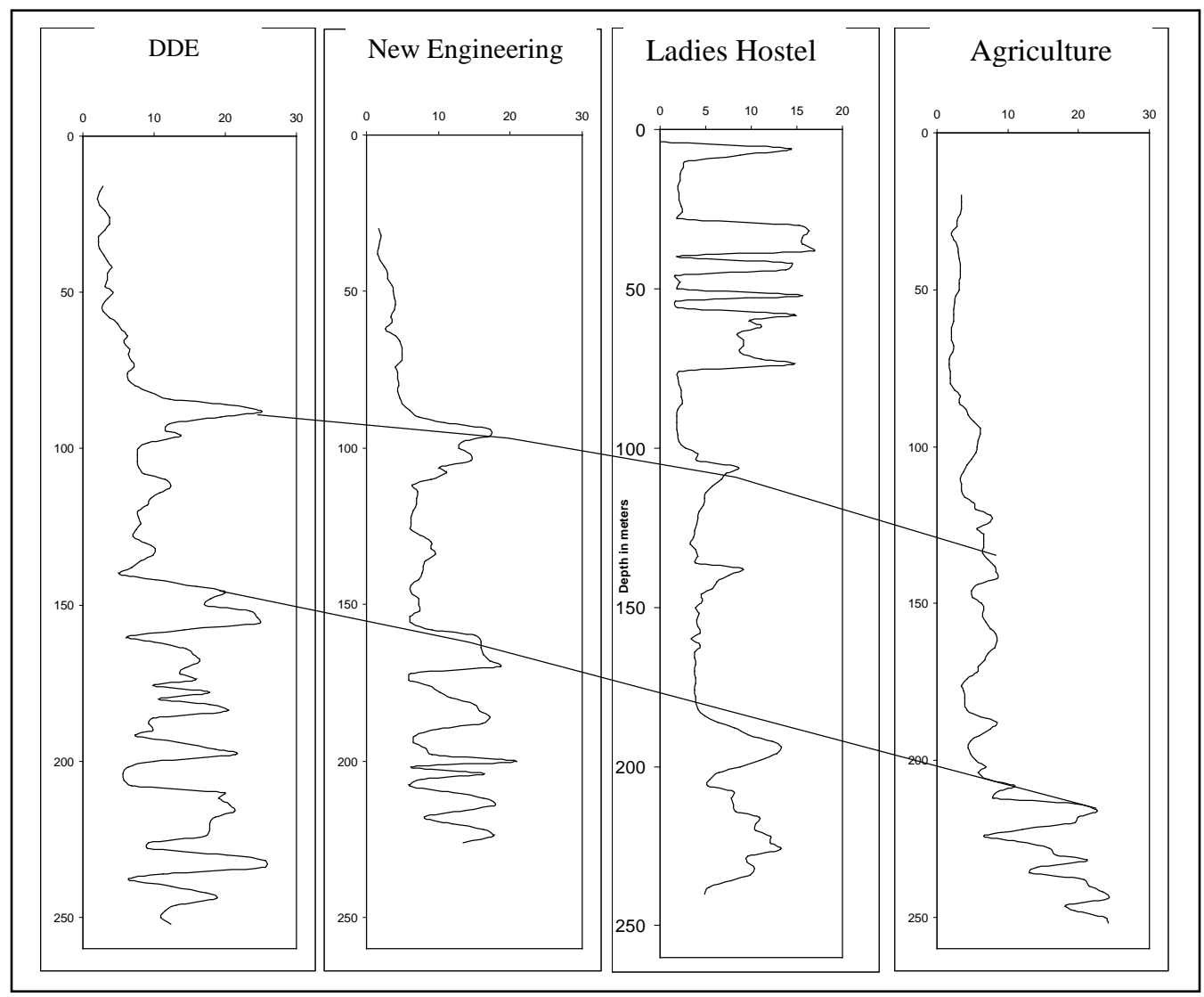

Fig 2. Bore hole resistivity log of four locations in the study area along AA'

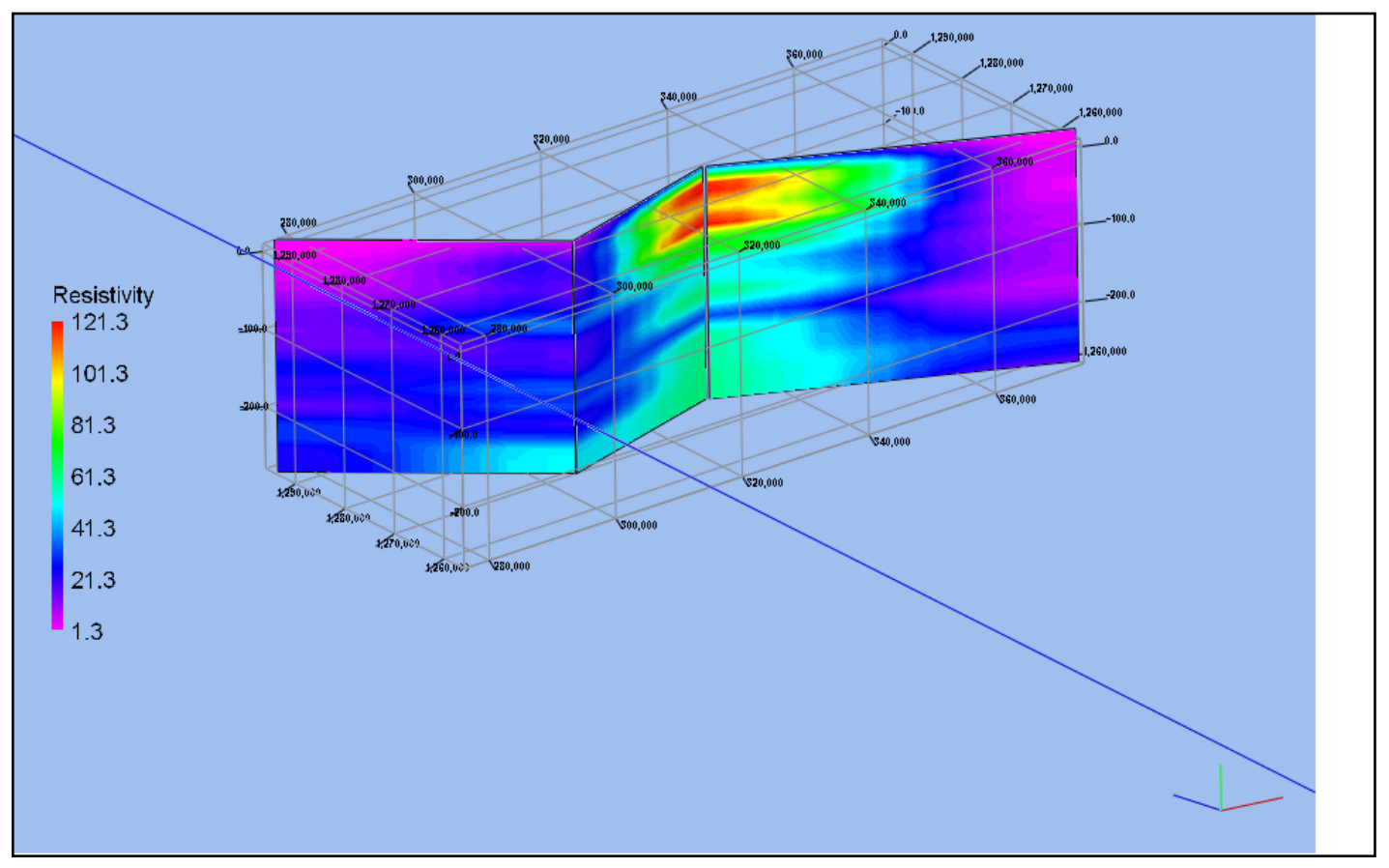

Fig 3. 3D representation of resistivity log of four locations in the study area 


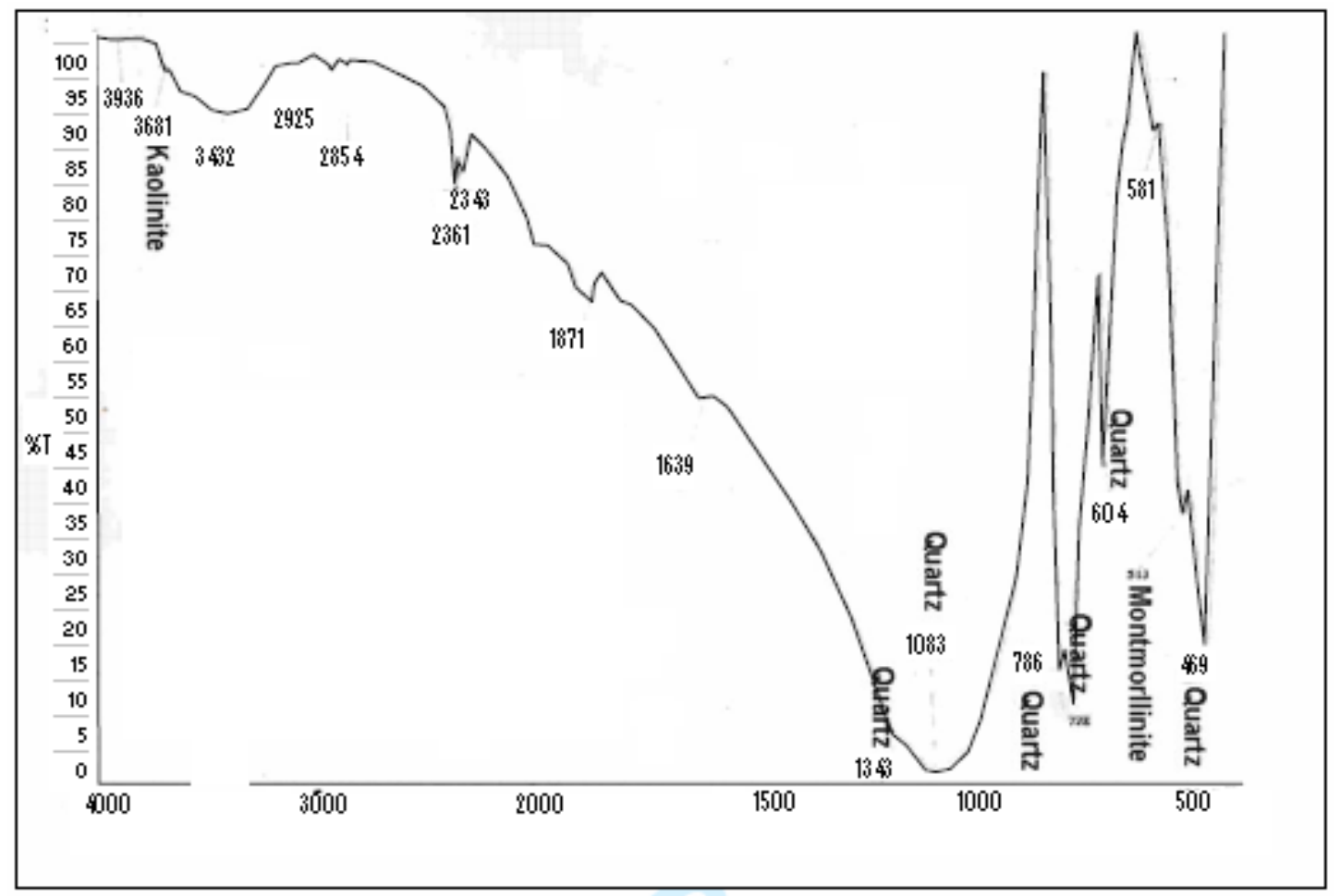

Fig 4: FTIR result in depth 30 meter

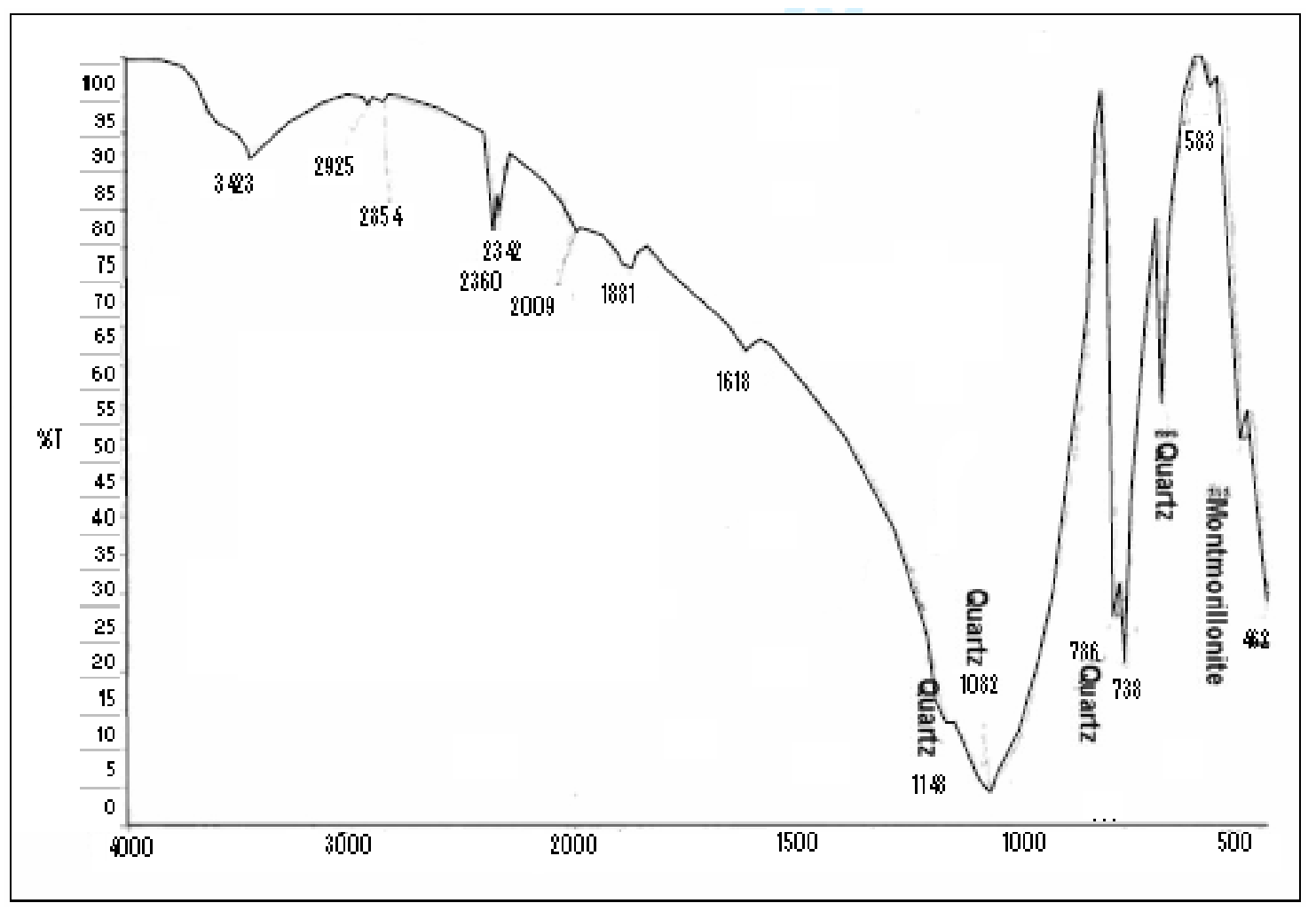

Fig 5: FTIR result in depth 85 meter 


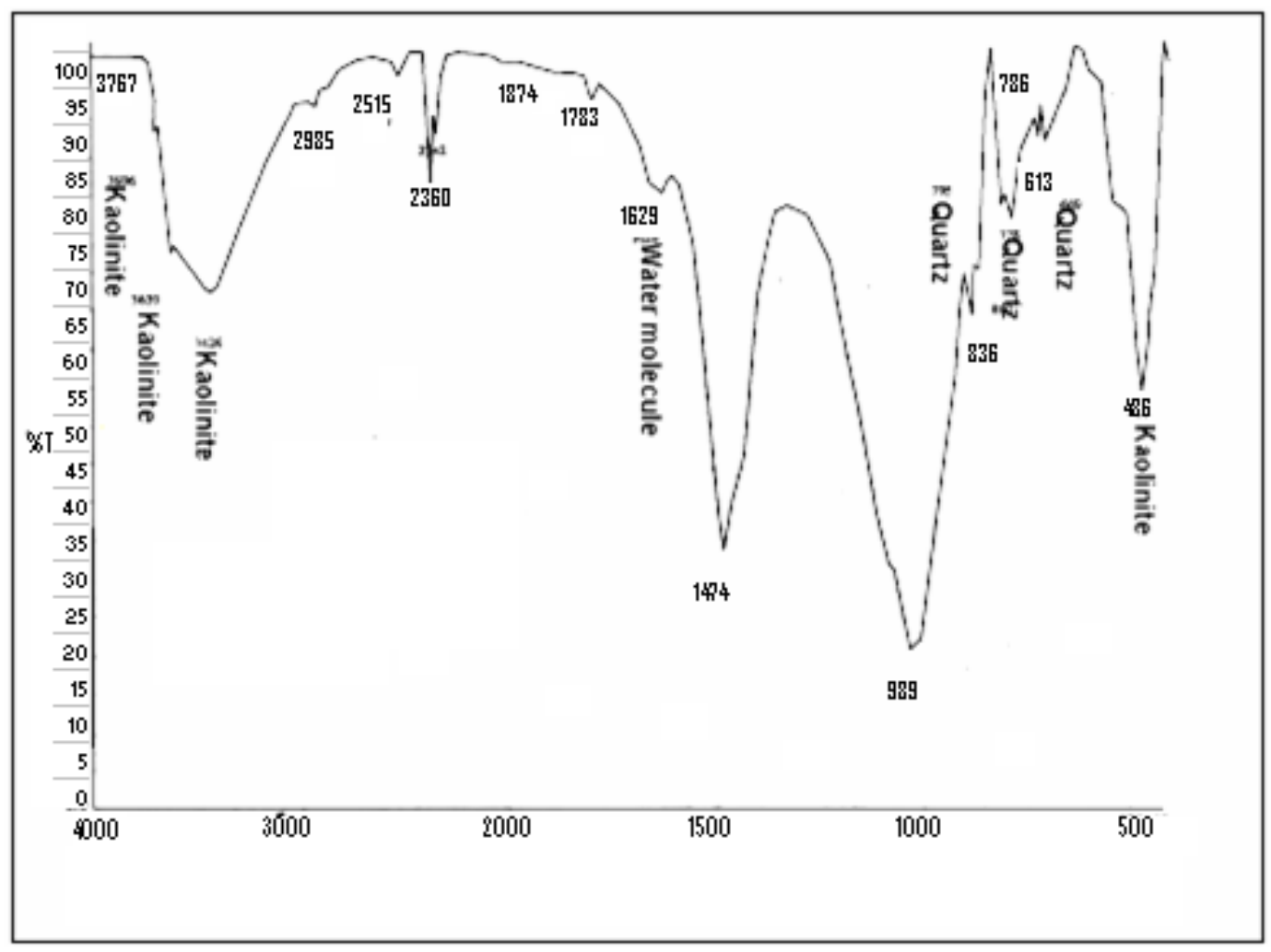

Fig 6: FTIR result in depth 197 meter 

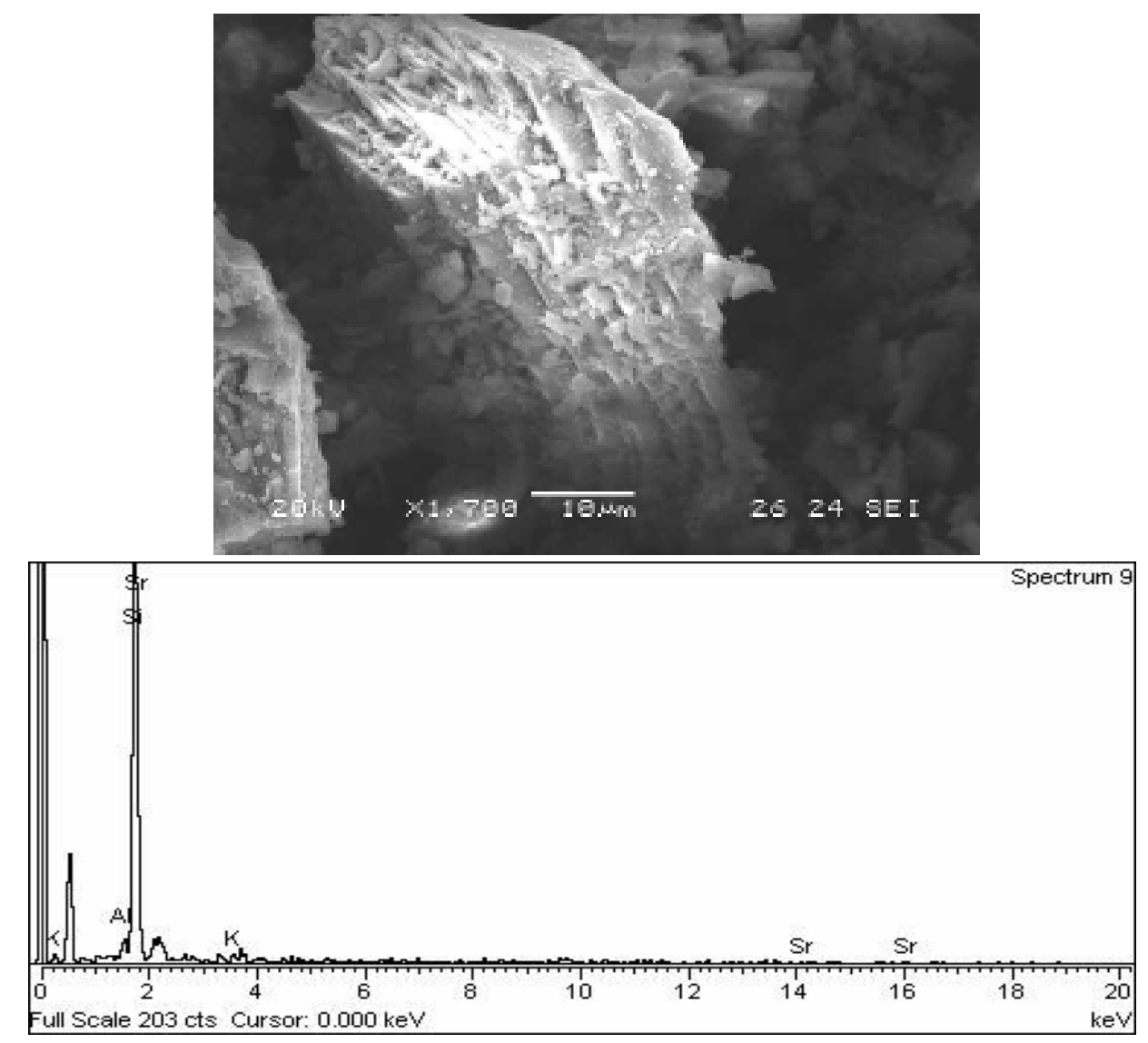

Fig 7: SEM photograph in depth $27 \mathrm{~m}(10 \mu \mathrm{m})$
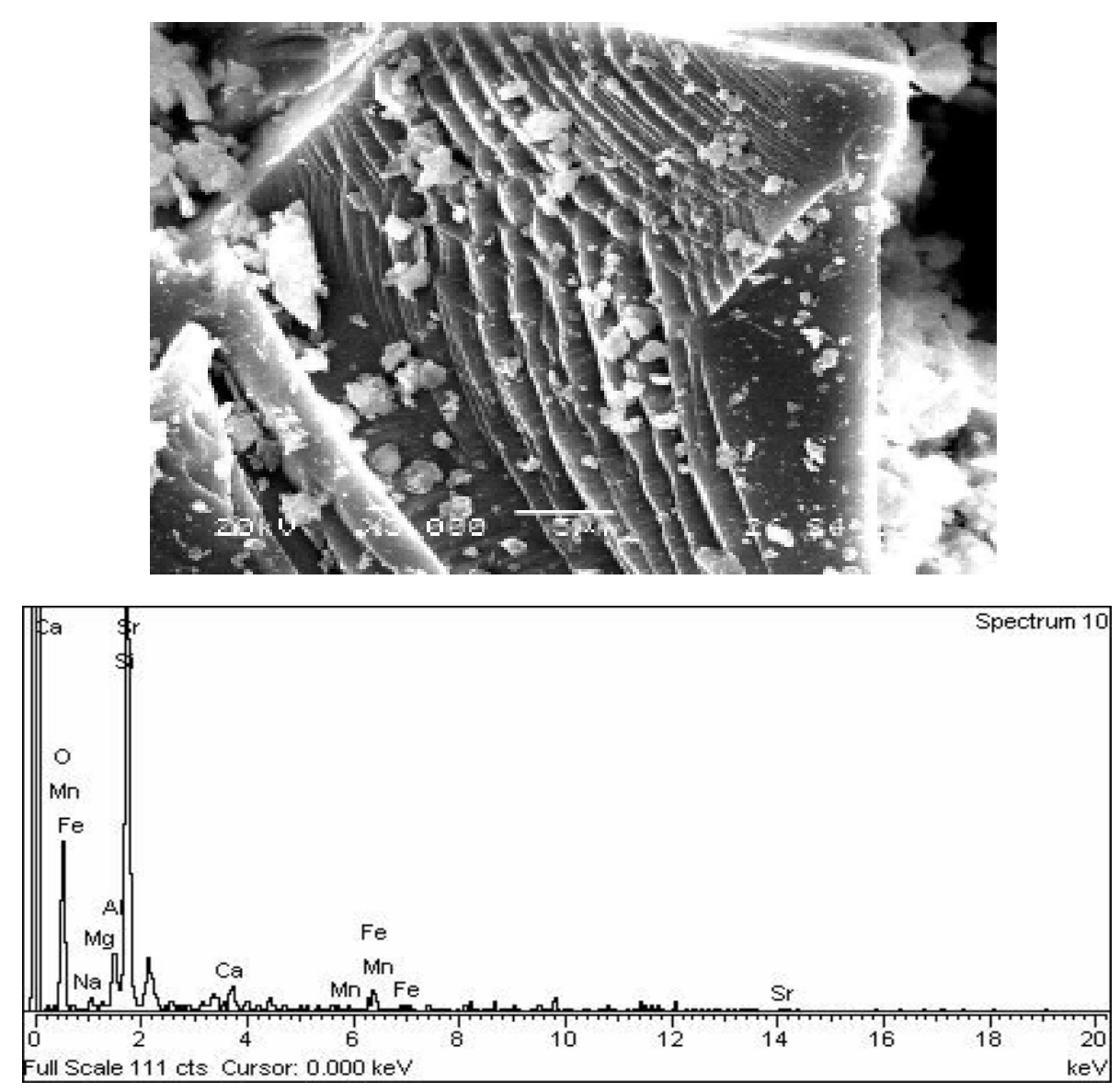

Fig 7: SEM photograph in depth $27 \mathrm{~m}$ ( $5 \mu \mathrm{m}$ ) 

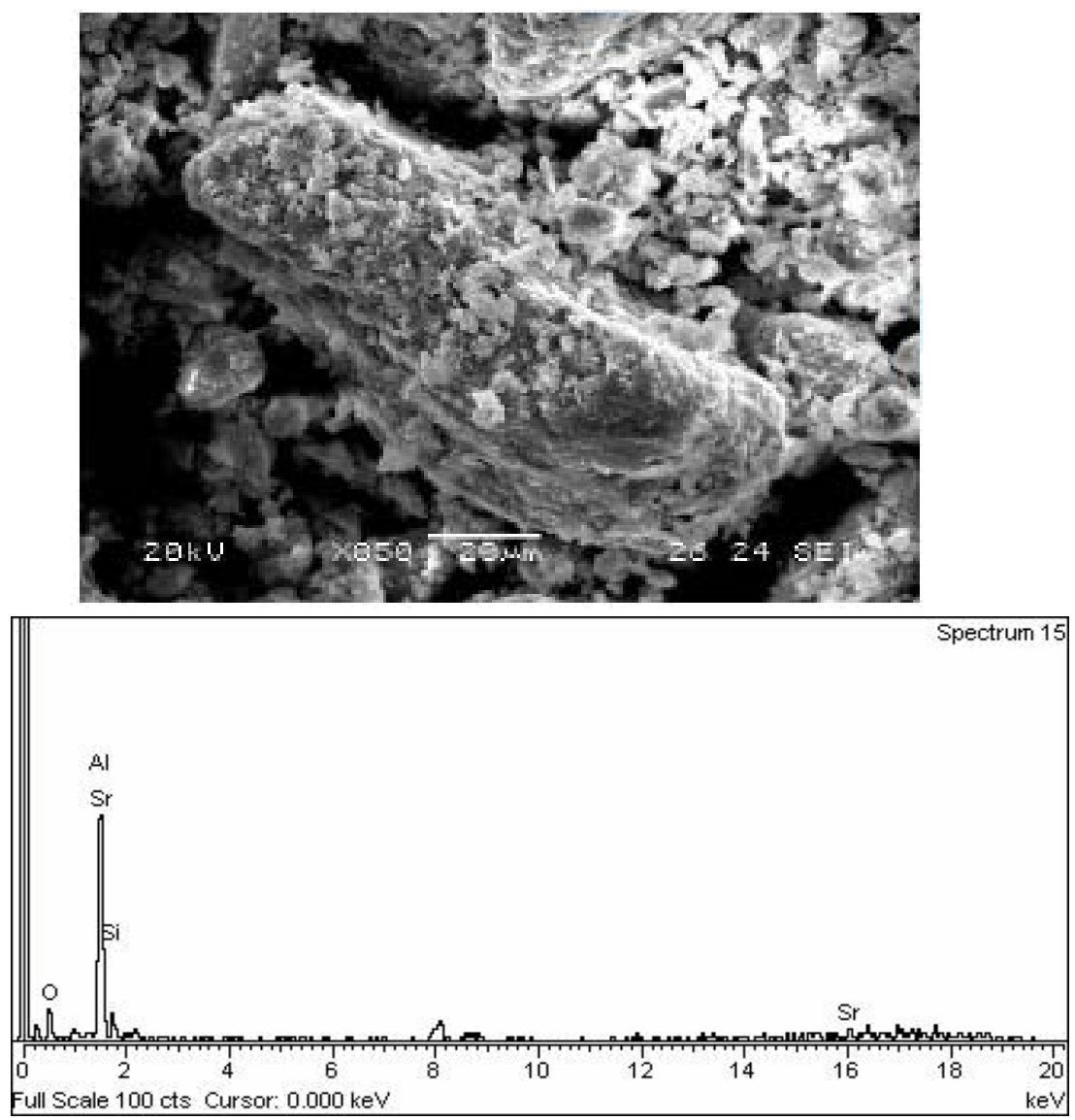

Fig 8: SEM photograph in depth $197 \mathrm{~m}(20 \mu \mathrm{m})$
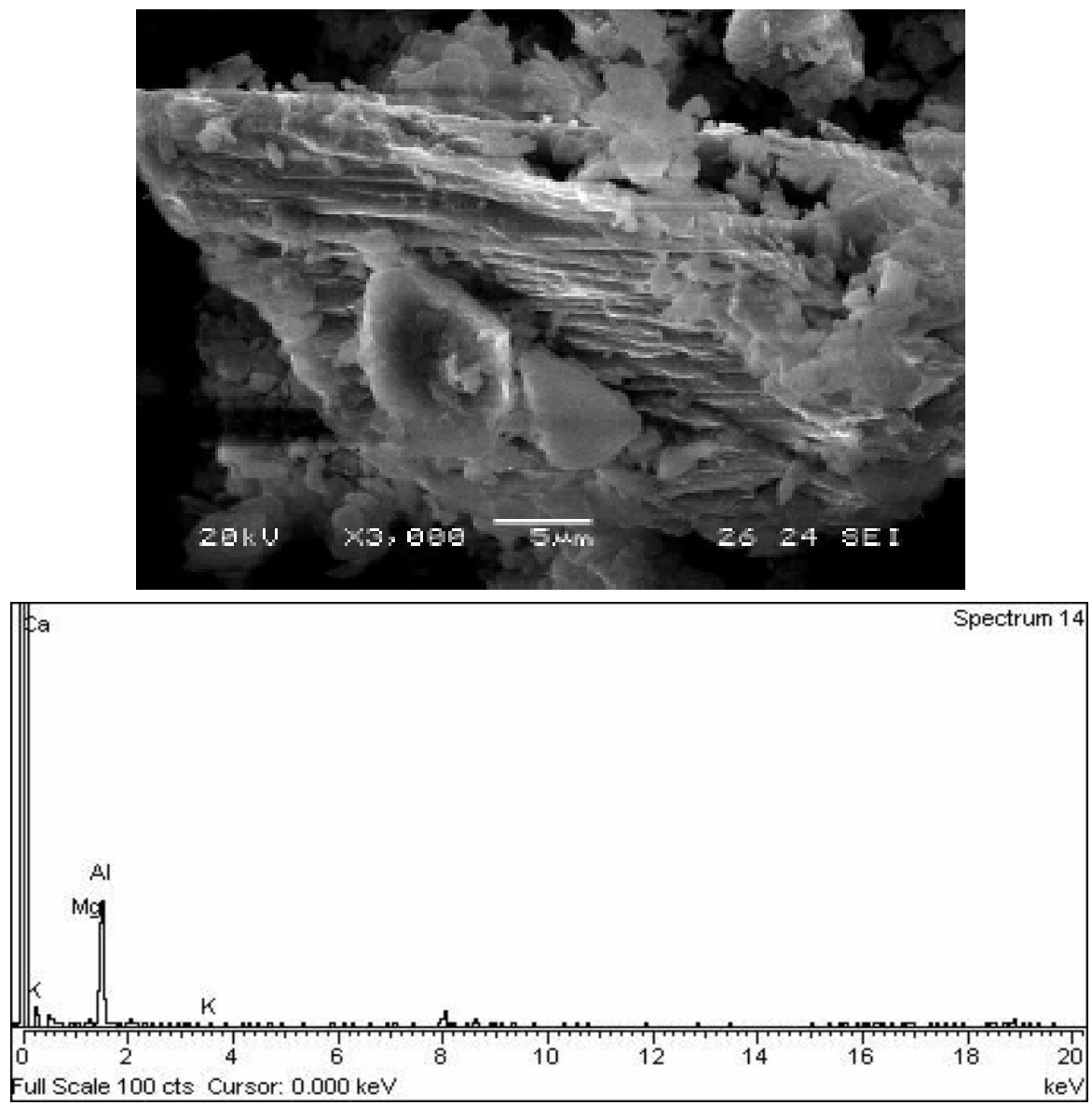

Fig 8: SEM photograph in depth 197m ( $5 \mu \mathrm{m}$ ) 


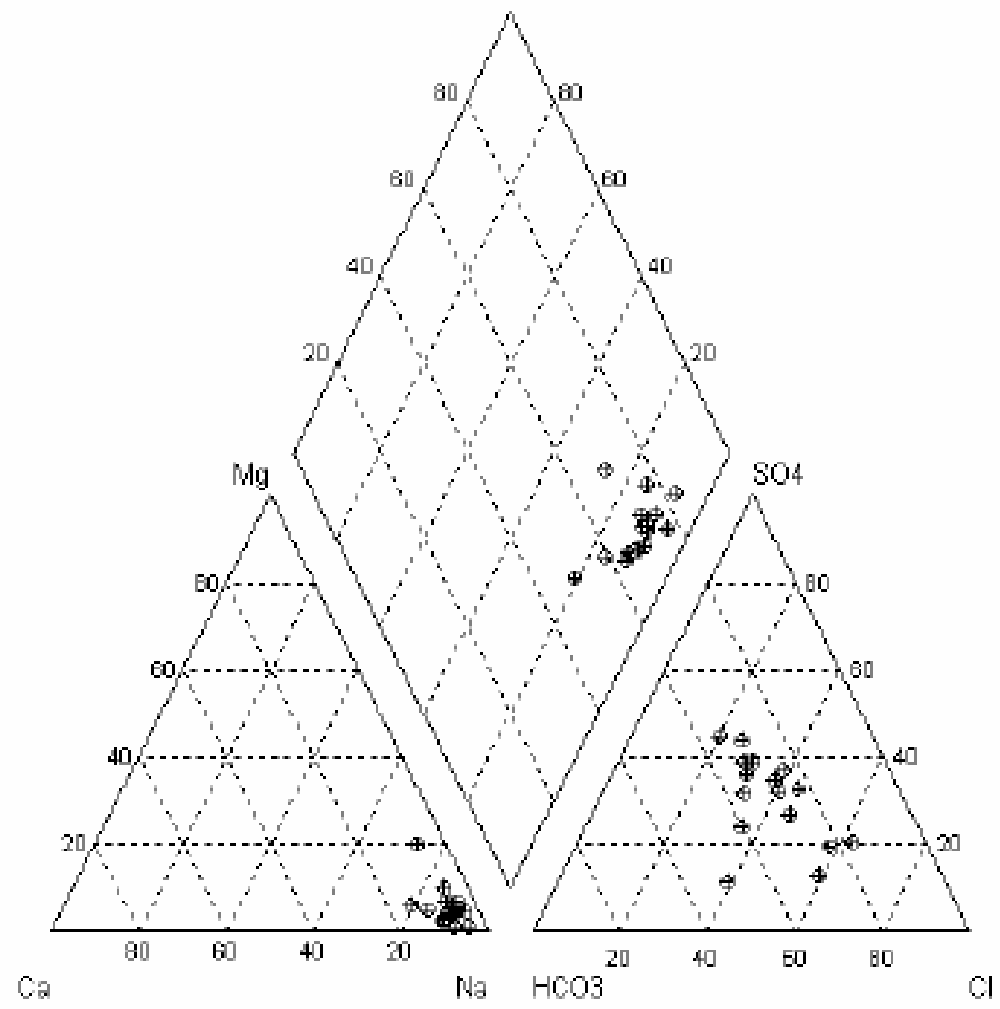

Fig 9: Piper diagram in Shallow groundwater

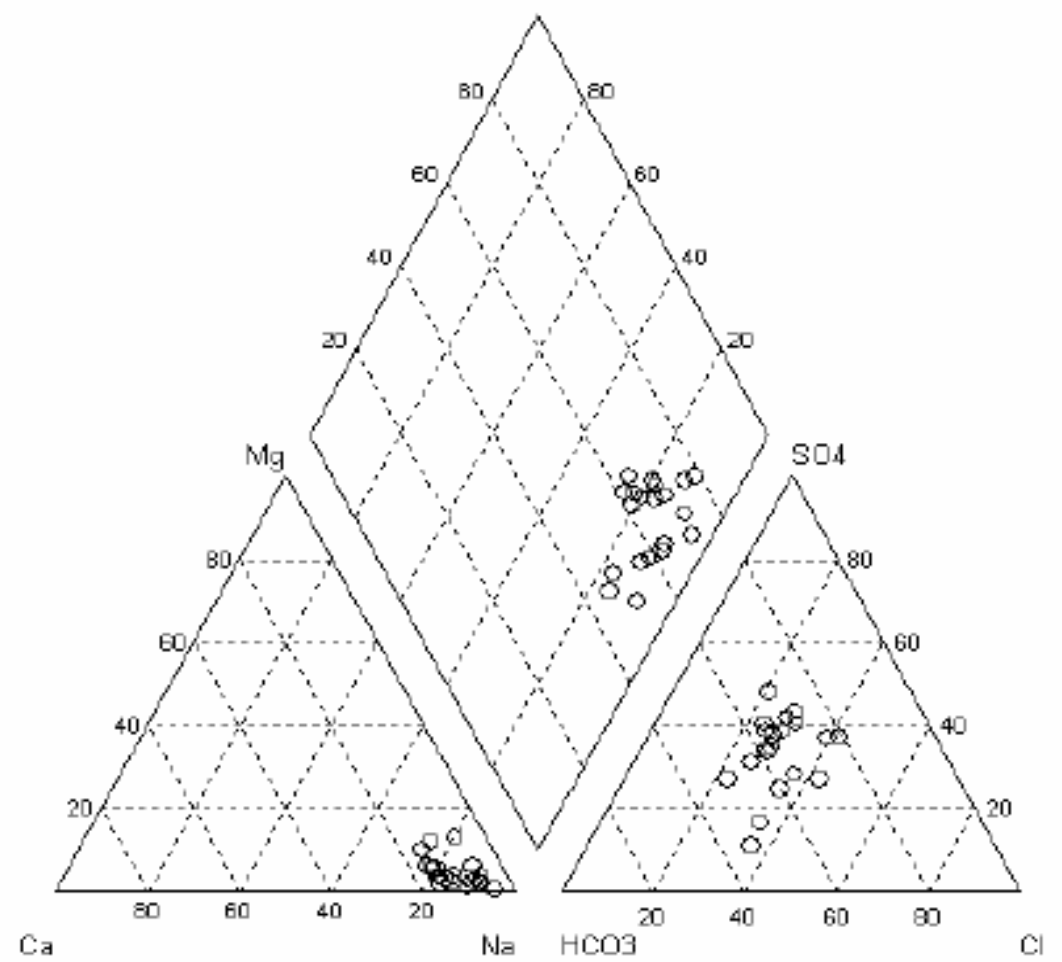

Fig 10: Piper diagram in deeper groundwater 


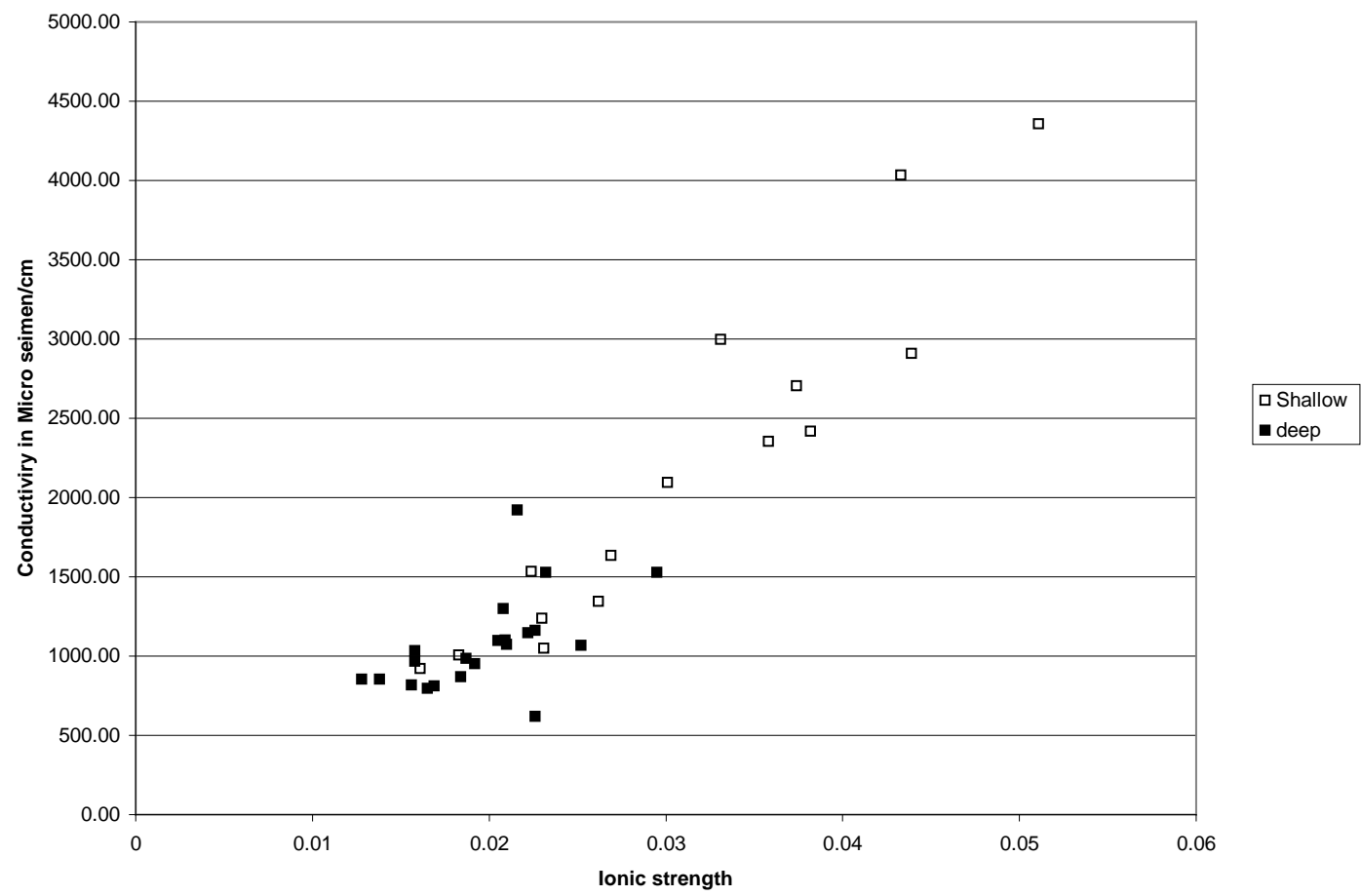

Fig 11: Ratio of Ionic strength to EC

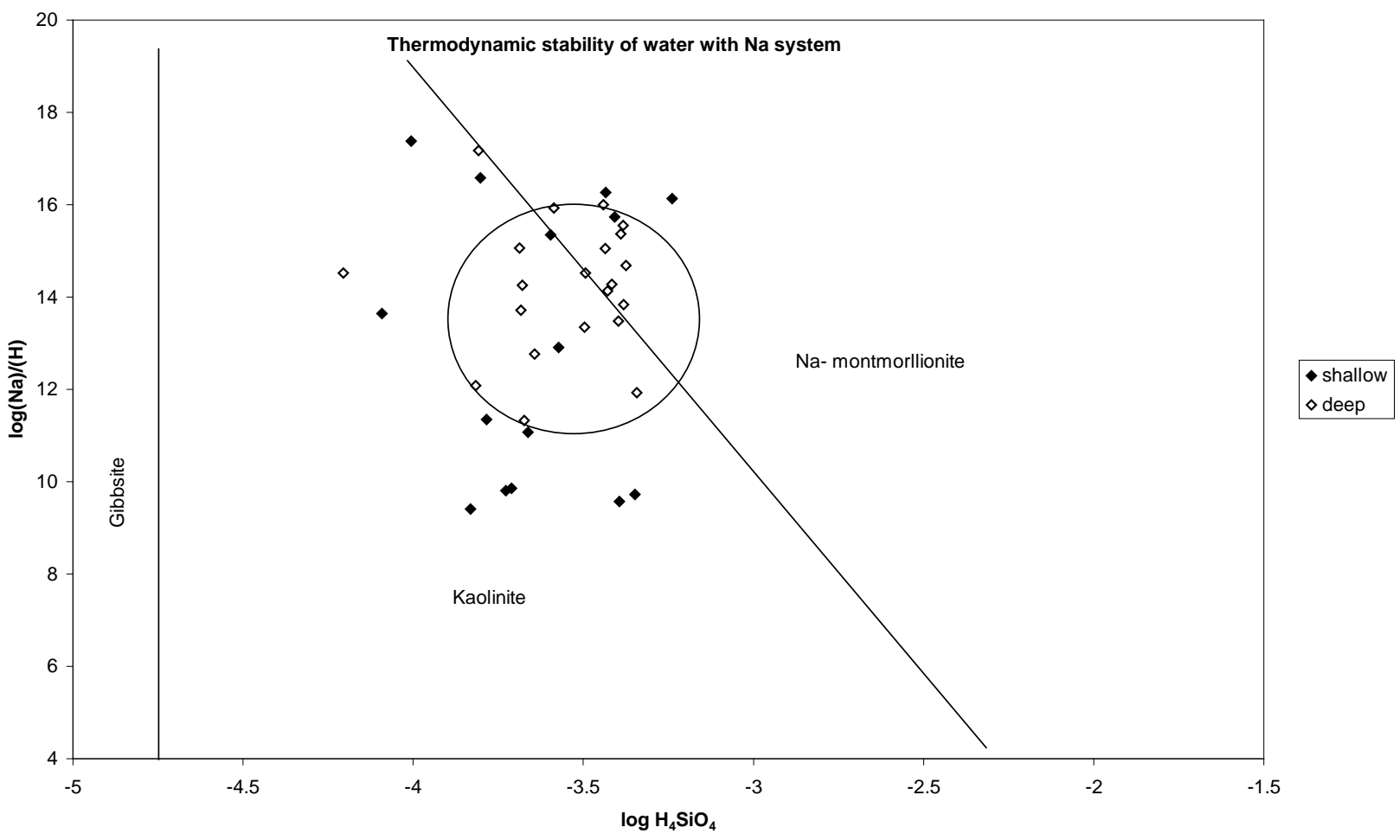

Fig 12: Themodynamic stability of Na System 


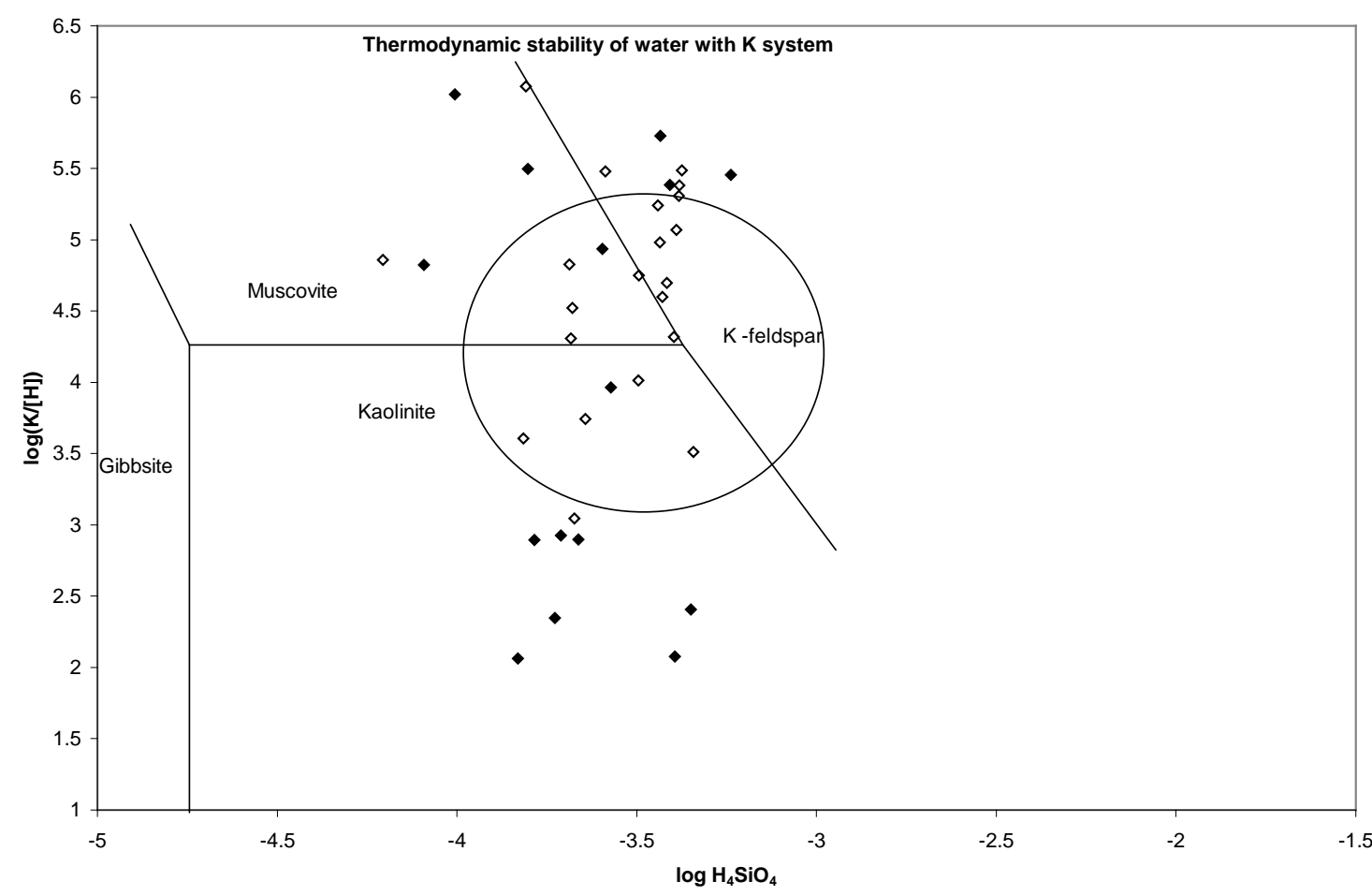

- shallow $\diamond$ deep

Fig 13: Themodynamic stability of K System

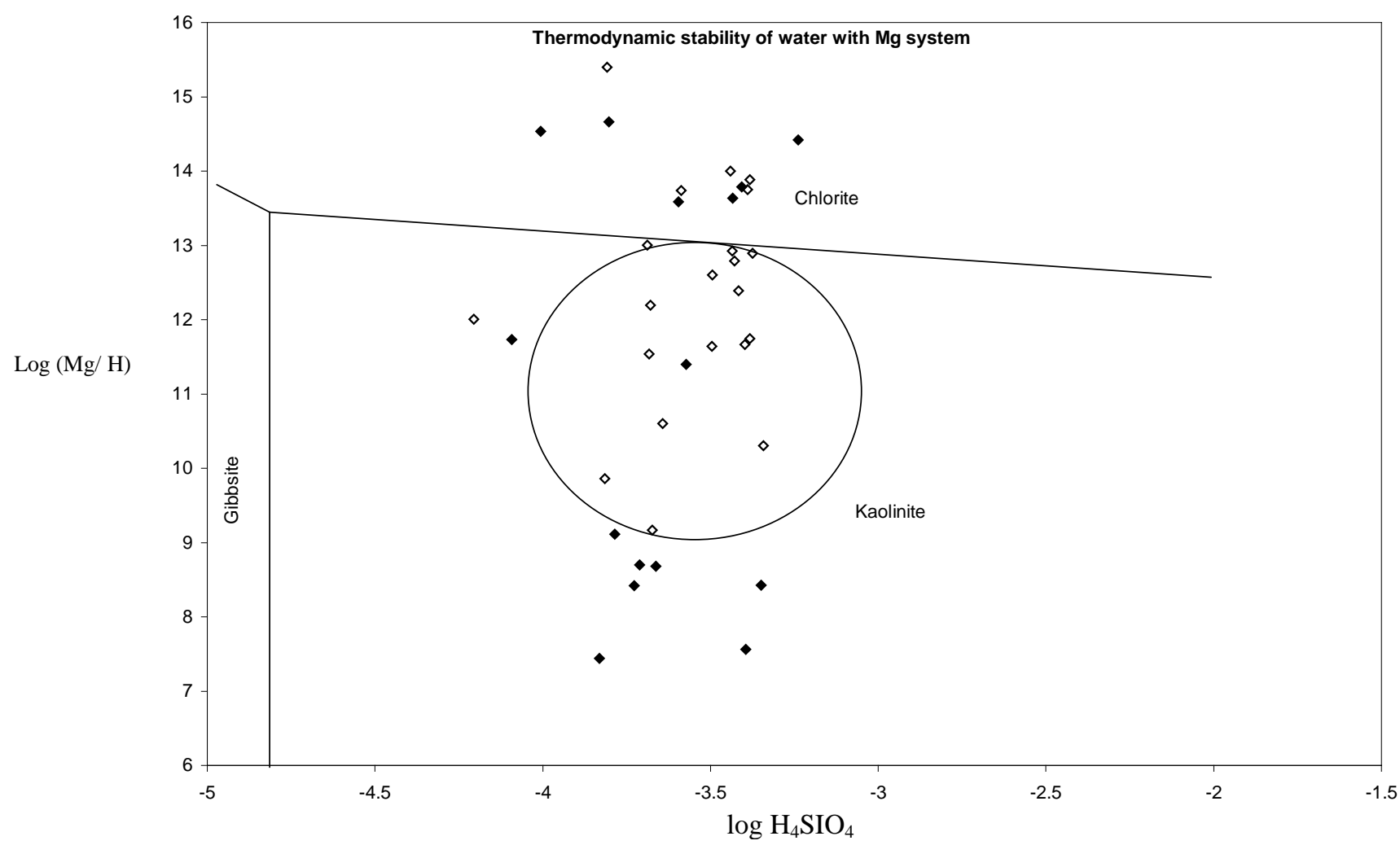

$\checkmark$ shallow $\diamond$ deep

Fig 14: Themodynamic stability of Mg System 


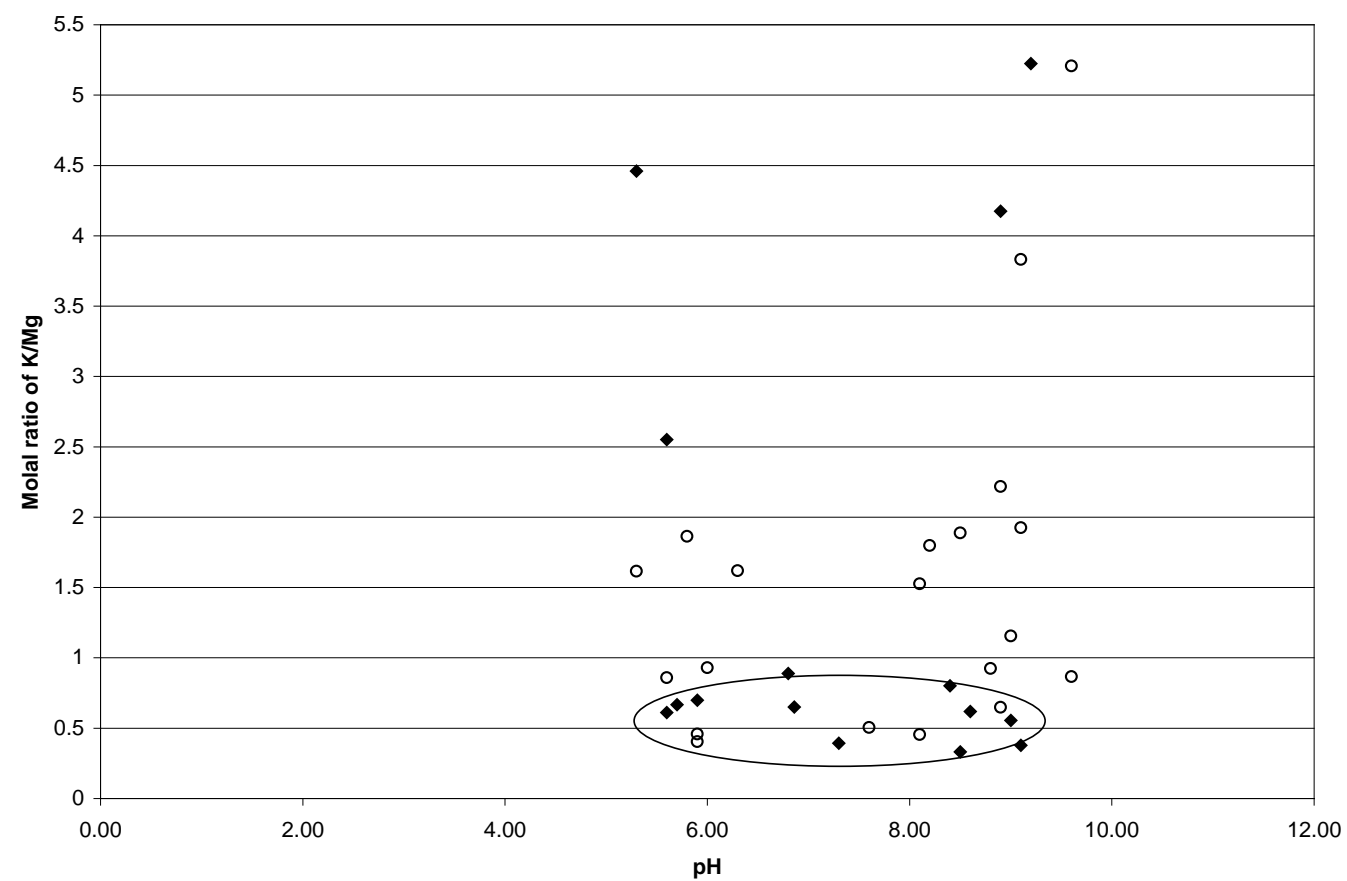

- Shallow

Fig 15: Molal ratio of $\mathrm{K} / \mathrm{Mg}$ in the ground water

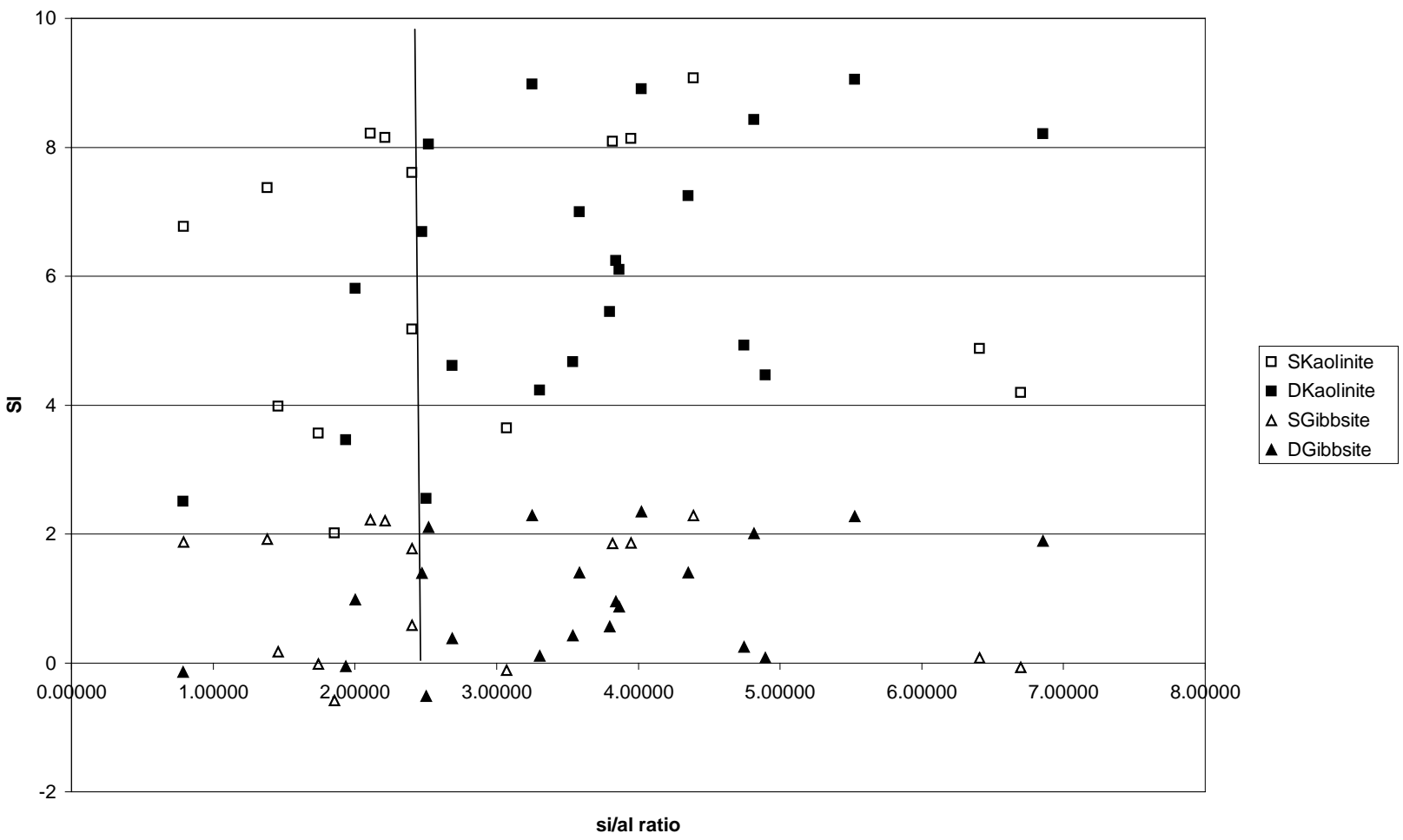

Fig 16: Silicate minerals $\mathrm{SI}_{\text {Gibbsite }}$ and $\mathrm{SI}_{\text {Kaolinite }}$ 


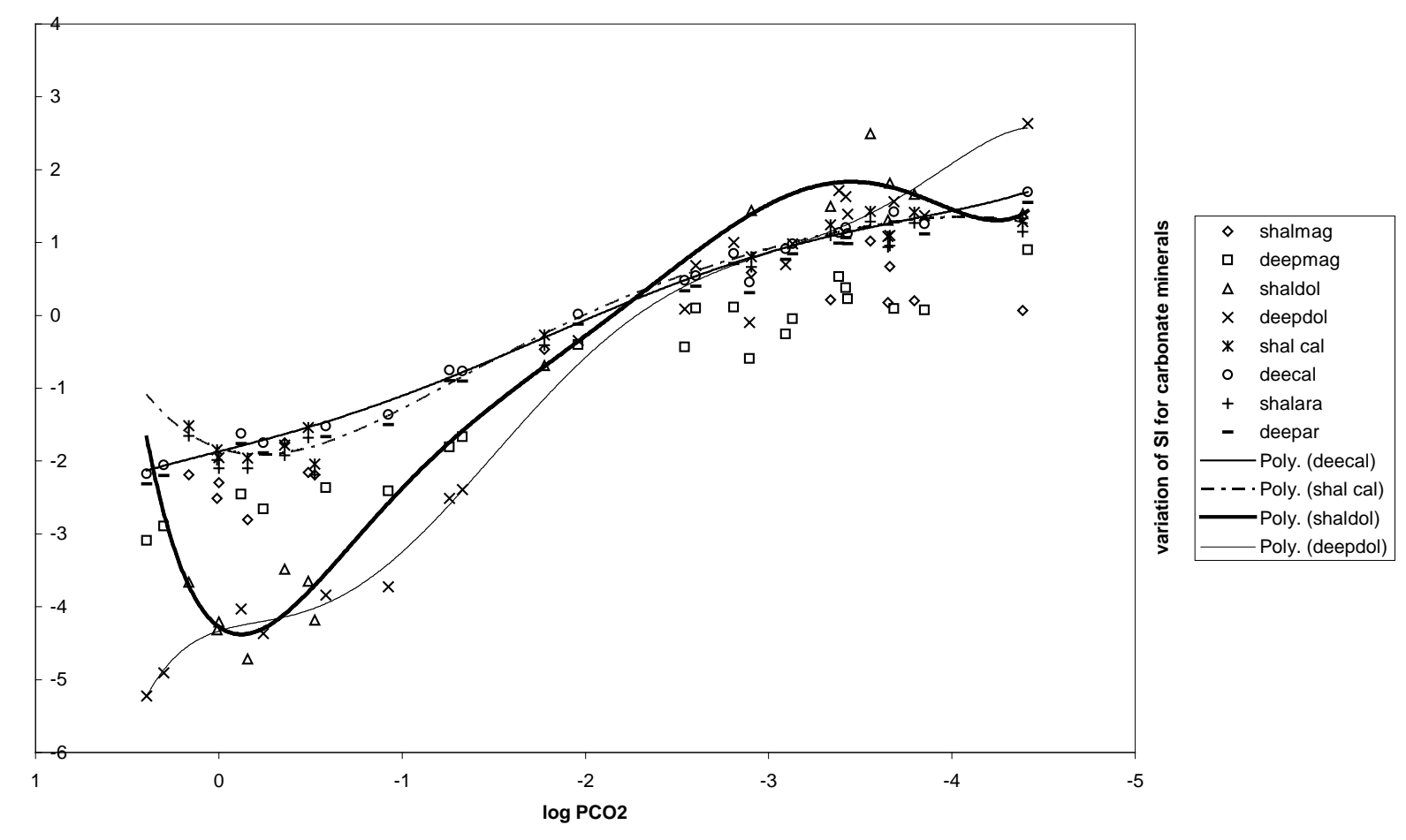

Fig 17: Variation of Saturation index of calcite, dolomite and aragonite with $\mathrm{PCO}_{2}$ 
Table 1 : Geology of the study area (Lakshmanan, 1982)

\begin{tabular}{|c|c|c|l|}
\hline Age & $\begin{array}{c}\text { Interval } \\
\text { (m) }\end{array}$ & $\begin{array}{c}\text { Thickness } \\
\text { (m) }\end{array}$ & \multicolumn{1}{|c|}{ Lithology } \\
\hline $\begin{array}{c}\text { Pliocene } \\
\text { to recent }\end{array}$ & $0-165$ & 165 & Coarse to fine sand and clay \\
\hline Miocene & $165-445$ & 280 & Coarse to fine sand and limestone \\
\hline Oligocene & $445-555$ & 110 & Crypto crystalline limestone \\
\hline Eocene & $555-1967$ & 1412 & $\begin{array}{l}\text { Clay stone, splitting cryptocrystalline } \\
\text { limestone and fine-grained sand stone. }\end{array}$ \\
\hline Paleocene & $1967-2563$ & 596 & $\begin{array}{l}\text { Splintery shale siltstone and fine grained } \\
\text { sand stone }\end{array}$ \\
\hline
\end{tabular}

Table 2 Summary of FTIR analysis of bore samples at different depths.

\begin{tabular}{|c|c|c|c|}
\hline S.No & Depth (ft) & Lithology & Minerals identified by FTIR analysis \\
\hline 1 & $10-20$ & Silty sand & $\begin{array}{l}\text { Dominantly with Quartz, with few Kaolinite and } \\
\text { Montmorllionite. }\end{array}$ \\
\hline 2 & $90-100$ & Clay & $\begin{array}{l}\text { Dominantly orthoclase, Kaolinite, montmorllionite } \\
\text { and few quartz }\end{array}$ \\
\hline 3 & $100-110$ & Sand & Dominantly of Quartz \\
\hline 4 & $180-190$ & $\begin{array}{l}\text { Sandstone } \\
\text { with shells }\end{array}$ & $\begin{array}{l}\text { Dominantly of Orthoclase, with minor quartz and } \\
\text { Calcite }\end{array}$ \\
\hline 5 & $270-280$ & Clay & $\begin{array}{l}\text { Dominantly with Orthoclase, Kaolinite and few } \\
\text { quartz }\end{array}$ \\
\hline 6 & $640-650$ & Sand & Dominantly of Quartz \\
\hline
\end{tabular}


Table 4: Correlation analysis of Shallow and Deep Ground waters

\begin{tabular}{|c|c|c|c|c|c|c|c|c|c|c|c|}
\hline \multicolumn{12}{|c|}{ Shallow groundwater } \\
\hline & $\mathrm{Ca}^{+}$ & $\mathrm{Mg}^{++}$ & $\mathrm{Na}^{+}$ & $\mathrm{K}^{+}$ & $\mathrm{HCO}_{3}^{-}$ & $\mathrm{Cl}^{-}$ & $\mathrm{SO}_{4}{ }^{2-}$ & $\mathrm{H}_{4} \mathrm{SIO}_{4}$ & $\mathrm{pH}$ & EC & TDS \\
\hline $\mathrm{Ca}^{+}$ & 1 & & & & & & & & & & \\
\hline $\mathrm{Mg}^{++}$ & 0.3 & 1 & & & & & & & & & \\
\hline $\mathrm{Na}^{+}$ & 0.531 & 0.456 & 1 & & & & & & & & \\
\hline $\mathrm{K}^{+}$ & 0.423 & 0.304 & 0.232 & 1 & & & & & & & \\
\hline $\mathrm{HCO}_{3}^{-}$ & 0.789 & 0.42 & 0.779 & 0.497 & 1 & & & & & & \\
\hline $\mathrm{Cl}^{-}$ & 0.604 & 0.578 & 0.942 & 0.375 & 0.757 & 1 & & & & & \\
\hline $\mathrm{SO}_{4}^{2-}$ & 0.083 & 0.309 & 0.645 & 0.184 & 0.447 & 0.437 & 1 & & & & \\
\hline $\mathrm{H}_{4} \mathrm{SIO}_{4}$ & 0.227 & 0.244 & 0.261 & 0.37 & 0.151 & 0.302 & 0.285 & 1 & & & \\
\hline $\mathrm{pH}$ & -0.16 & 0.014 & 0.208 & -0.05 & 0.092 & 0.054 & 0.466 & 0.201 & 1 & & \\
\hline $\mathrm{EC}$ & 0.611 & 0.574 & 0.931 & 0.399 & 0.789 & 0.981 & 0.446 & 0.3 & 0.052 & 1 & \\
\hline TDS & 0.615 & 0.542 & 0.927 & 0.395 & 0.778 & 0.975 & 0.426 & 0.29 & 0.096 & 0.987 & 1 \\
\hline \multicolumn{12}{|c|}{ Deep groundwater } \\
\hline & $\mathrm{Ca}^{+}$ & $\mathrm{Mg}^{++}$ & $\mathrm{Na}^{+}$ & $\mathrm{K}^{+}$ & $\mathrm{HCO}_{3}^{-}$ & $\mathrm{Cl}^{-}$ & $\mathrm{SO}_{4}{ }^{2-}$ & $\mathrm{H}_{4} \mathrm{SIO}_{4}$ & $\mathrm{pH}$ & EC & TDS \\
\hline $\mathrm{Ca}^{+}$ & 1 & & & & & & & & & & \\
\hline $\mathrm{Mg}^{++}$ & 0.321 & 1 & & & & & & & & & \\
\hline $\mathrm{Na}^{+}$ & 0.19 & 0.057 & 1 & & & & & & & & \\
\hline $\mathrm{K}^{+}$ & 0.468 & 0.283 & 0.047 & 1 & & & & & & & \\
\hline $\mathrm{HCO}_{3}^{-}$ & -0.05 & 0.186 & 0.541 & 0.171 & 1 & & & & & & \\
\hline $\mathrm{Cl}^{-}$ & 0.344 & 0.247 & 0.849 & 0.281 & 0.406 & 1 & & & & & \\
\hline $\mathrm{SO}_{4}{ }^{2-}$ & 0.367 & 0.106 & 0.764 & 0.12 & 0.148 & 0.606 & 1 & & & & \\
\hline $\mathrm{H}_{4} \mathrm{SIO}_{4}$ & 0.184 & 0.428 & -0.16 & 0.479 & 0.098 & -0.07 & 0.08 & 1 & & & \\
\hline $\mathrm{pH}$ & 0.181 & -0.1 & 0.348 & 0.199 & 0.204 & 0.16 & 0.618 & 0.107 & 1 & & \\
\hline $\mathrm{EC}$ & 0.431 & 0.142 & 0.876 & 0.308 & 0.411 & 0.944 & 0.662 & -0.09 & 0.239 & 1 & \\
\hline TDS & 0.445 & 0.182 & 0.868 & 0.327 & 0.414 & 0.949 & 0.664 & -0.06 & 0.265 & 0.996 & 1 \\
\hline
\end{tabular}


Table 5: Factor analysis in Shallow and Deep groundwater

\begin{tabular}{|c|c|c|c|c|c|c|c|c|}
\hline \multicolumn{4}{|c|}{$\begin{array}{l}\text { Shallow groundwater-Rotated Component } \\
\text { Matrix }\end{array}$} & \multicolumn{5}{|c|}{ Deep Groundwater - Rotated Component Matrix } \\
\hline & \multicolumn{3}{|c|}{ Component } & & \multicolumn{4}{|c|}{ Component } \\
\hline & 1 & 2 & 3 & & 1 & 2 & 3 & 4 \\
\hline $\mathrm{Ca}^{+}$ & 0.707 & -0.33 & 0.306 & $\mathrm{Ca}^{+}$ & 0.407 & 0.49 & 0.107 & -0.61 \\
\hline $\mathrm{Mg}^{++}$ & 0.553 & 0.012 & 0.261 & $\mathrm{Mg}^{++}$ & 0.171 & 0.716 & -0.268 & 0.012 \\
\hline $\mathrm{Na}^{+}$ & 0.921 & 0.337 & -0.11 & $\mathrm{Na}^{+}$ & 0.897 & 0.021 & 0.271 & 0.254 \\
\hline $\mathrm{K}^{+}$ & 0.314 & -0.15 & 0.777 & $\mathrm{~K}^{+}$ & 0.181 & 0.752 & 0.139 & -0.14 \\
\hline $\mathrm{HCO}_{3}{ }^{-}$ & 0.862 & 0.015 & 0.205 & $\mathrm{HCO}_{3}{ }^{-}$ & 0.404 & 0.205 & 0.005 & 0.798 \\
\hline $\mathrm{Cl}^{-}$ & 0.948 & 0.122 & 0.151 & $\mathrm{Cl}^{-}$ & 0.955 & 0.128 & 0.0312 & 0.012 \\
\hline $\mathrm{SO}_{4}{ }^{2-}$ & 0.413 & 0.745 & 0.113 & $\mathrm{SO}_{4}{ }^{2-}$ & 0.637 & 0.021 & 0.638 & -0.11 \\
\hline $\mathrm{H}_{4} \mathrm{SIO}_{4}$ & 0.012 & 0.308 & 0.803 & $\mathrm{H}_{4} \mathrm{SIO}_{4}$ & -0.23 & 0.819 & 0.197 & 0.13 \\
\hline $\mathrm{pH}$ & 0.021 & 0.854 & 0.021 & $\mathrm{pH}$ & 0.139 & 0.022 & 0.937 & 0.021 \\
\hline EC & 0.953 & 0.116 & 0.166 & EC & 0.972 & 0.012 & 0.112 & 0.005 \\
\hline TDS & 0.945 & 0.129 & 0.157 & TDS & 0.966 & 0.138 & 0.125 & 0.021 \\
\hline Eigen value & 5.961 & 1.535 & 1.103 & Eigen value & 4.463 & 2.092 & 1.532 & 1.128 \\
\hline Cumulative \% & 48.88 & 64.15 & 78.17 & Cumulative \% & 40.58 & 59.59 & 73.521 & 83.78 \\
\hline
\end{tabular}


Table 3: Geochemical data in Shallow and deep groundwater samples

\begin{tabular}{|c|c|c|c|c|c|c|c|c|c|c|c|c|c|c|}
\hline \multicolumn{15}{|c|}{ Shallow water } \\
\hline & Location & Depth(ft) & Lothology & $\mathrm{Ca}^{+}$ & $\mathrm{Mg}^{++}$ & $\mathrm{Na}^{+}$ & $\mathrm{K}^{+}$ & $\mathrm{HCO}_{3}^{-}$ & $\mathrm{Cl}^{-}$ & $\mathrm{SO}_{4}^{2-}$ & $\mathrm{H}_{4} \mathrm{SIO}_{4}$ & $\mathrm{pH}$ & $\mathrm{EC}$ & TDS \\
\hline & Vatakkiruppu 1 & 25 & Silty sand & 55.99 & 19.2 & 771.59 & 79.6 & 634.4 & 762.17 & 219.18 & 4.8 & 5.6 & 4033 & 2206 \\
\hline 2 & Vatakkiruppu 2 & 22 & Silty sand & 23.99 & 43.19 & 304 & 49 & 366 & 212.7 & 370 & 11.6 & 5.9 & 1344 & 711 \\
\hline 3 & Thamarai illam & 40 & Sandy clay & 32 & 9.59 & 502.4 & 12.5 & 443.6 & 230.42 & 420 & 12.8 & 8.4 & 1528 & 830 \\
\hline 4 & Near sivan temple & 26 & Silty sand & 40 & 9.59 & 321.03 & 69.5 & 414.8 & 212.7 & 194.67 & 25.2 & 5.3 & 1920 & 1060 \\
\hline 5 & Dental back & 26 & Silty sand & 31.99 & 4.79 & 353.23 & 12.6 & 341.6 & 177.25 & 235.11 & 13.6 & 8.6 & 1099 & 1035 \\
\hline 6 & Near medical library & 24 & Silty sand & 32 & 19.2 & 670.21 & 11.82 & 512.4 & 478.58 & 382.71 & 11.6 & 9.1 & 2703 & 1507 \\
\hline 7 & Main bumb station & 28 & Silty clay & 40 & 14.4 & 644.26 & 14.31 & 439.2 & 407.67 & 525 & 24 & 5.6 & 2418 & 1250 \\
\hline 8 & University canteen & 41 & Sandy clay & 40 & 9.59 & 243.1 & 10.4 & 390.4 & 177.25 & 70 & 24.4 & 5.7 & 1034 & 587 \\
\hline 9 & E1 hostel & 40 & Sandy clay & 24 & 14.39 & 359.16 & 13 & 292.8 & 248.15 & 267.45 & 40.8 & 9 & 1535 & 815 \\
\hline 10 & V C Bangalow & 28 & Silty clay & 31.99 & 33.59 & 554.83 & 21.51 & 366 & 549.47 & 246.71 & 16 & 7.3 & 2998 & 1621 \\
\hline 11 & Eng. College & 30 & Silty Sandy clay & 31.99 & 4.79 & 345.32 & 14.7 & 366 & 124.08 & 370 & 12.4 & 6.8 & 619 & 349 \\
\hline 12 & Sivapuri road & 24 & Silty sand & 23 & 4.8 & 294.3 & 139.3 & 390.4 & 212.7 & 334.68 & 24.8 & 6.9 & 1526 & 864 \\
\hline 13 & Near vellakulam & 22 & Silty sand & 24 & 2.45 & 350.26 & 20.8 & 317.2 & 159.53 & 363.5 & 4.8 & 9.2 & 1146 & 643 \\
\hline 14 & Thiruvakkulam & 23 & Silty sand & 24 & 23.99 & 610.67 & 12.9 & 463.6 & 372.23 & 459.56 & 16 & 8.5 & 2353 & 1295 \\
\hline 15 & Kalingumedu & 18 & Sand & 32 & 4.79 & 820.64 & 32.5 & 488 & 549.47 & 550 & 25.2 & 8.9 & 2910 & 1638 \\
\hline 16 & Police station & 22 & Silty sand & 32 & 24 & 969.14 & 29.58 & 439.2 & 939.43 & 411.34 & 23.2 & 5.6 & 4358 & 2442 \\
\hline \multicolumn{15}{|c|}{ Deep water } \\
\hline 1 & Thamrai hostel & 780 & Sandy clay & 24 & 4.8 & 356.7 & 17.3 & 366 & 159.52 & 270.89 & 17.7 & 8.9 & 1102 & 611 \\
\hline 2 & Rose hostel(f) & 802 & Sandy clay & 40 & 9.59 & 252.55 & 13.5 & 317.2 & 141.8 & 270.89 & 16 & 9.6 & 951 & 531 \\
\hline 3 & Rose hostel(b) & 810 & Silty sand & 40 & 9.6 & 219.86 & 14.5 & 268.4 & 106.35 & 225 & 27.2 & 6 & 795.8 & 441 \\
\hline 4 & Medical mens hostel & 690 & Sand & 40 & 4.5 & 299.5 & 13.8 & 292.8 & 159.53 & 325 & 23.2 & 8.5 & 1074 & 606 \\
\hline 5 & Main pump station & 750 & Sandy clay & 47.99 & 19.19 & 265.84 & 12.6 & 268.4 & 159.53 & 170 & 11.2 & 5.9 & 1007 & 561 \\
\hline 6 & E3 hostel & 850 & Blu silty sand & 40 & 9.6 & 436.07 & 13.4 & 292.8 & 283.6 & 363.3 & 8.8 & 5.6 & 1634 & 915 \\
\hline 7 & Near tamil dept & 715 & Sand & 48 & 4.7 & 504.95 & 14.7 & 292.8 & 336.78 & 411.14 & 16 & 9.1 & 2095 & 1211 \\
\hline 8 & V.C. Bangalow & 720 & Sandy clay & 23.99 & 4.8 & 302 & 11.9 & 390.4 & 196.75 & 190 & 12.8 & 8.1 & 984 & 560 \\
\hline 9 & DDE & 710 & Sand & 32 & 4.79 & 196.78 & 14 & 219.6 & 86.85 & 270 & 23.6 & 8.2 & 816 & 463 \\
\hline 10 & Golden jublee hostel & 810 & silty sand & 40 & 9.59 & 235.72 & 14.4 & 292.8 & 124.07 & 203.44 & 27.6 & 8.8 & 811 & 484 \\
\hline 11 & Iyappan temple & 700 & Sand & 24 & 4.79 & 380.7 & 9 & 292.8 & 177.25 & 363.54 & 11.6 & 9 & 1050 & 587 \\
\hline
\end{tabular}




\begin{tabular}{|c|c|c|c|c|c|c|c|c|c|c|c|c|c|c|}
\hline 12 & Engineering & 840 & Silty sand & 32 & 4.79 & 218.7 & 12.6 & 244 & 124.08 & 230 & 19.2 & 6.3 & 965 & 484 \\
\hline 13 & Near dental & 940 & Blu silty sand & 24 & 4.79 & 196.87 & 14.5 & 366 & 141.8 & 60 & 24 & 5.8 & 855 & 464 \\
\hline 14 & OP 1 & 780 & Sandy clay & 16 & 19.19 & 219.86 & 14.3 & 244 & 194.97 & 170.99 & 26.8 & 5.9 & 922 & 532 \\
\hline 15 & OP 2 & 840 & Blu silty sand & 31.99 & 19.2 & 223.4 & 14.2 & 341.6 & 141.8 & 238.23 & 22.8 & 8.1 & 869 & 535 \\
\hline 16 & OP 3 & 745 & Sandy clay & 32 & 2.28 & 196.78 & 14.2 & 341.6 & 88.63 & 145.24 & 11.2 & 9.1 & 855 & 471 \\
\hline 17 & Agri-Chin & 780 & Sandy clay & 23 & 14.4 & 373.23 & 11.8 & 463.6 & 159.52 & 266.38 & 19.2 & 7.6 & 1161 & 647 \\
\hline 18 & Agri 1 & 648 & Sand & 24 & 9.59 & 425.3 & 10.1 & 414.8 & 159.52 & 370 & 24.8 & 8.9 & 1067 & 597 \\
\hline 19 & Agri 2 & 870 & Blu silty sand & 24 & 4.8 & 390 & 12.6 & 512.4 & 212.7 & 140 & 13.6 & 5.3 & 1300 & 728 \\
\hline 20 & Agri 3 & 851 & Blu silty sand & 15.99 & 1.43 & 403 & 12.1 & 317.2 & 194.98 & 352 & 10.2 & 9.6 & 1237 & 687 \\
\hline
\end{tabular}

